\title{
A meta-analysis of adjuvant therapy after potentially curative treatment for hepatocellular carcinoma
}

\author{
Jun Wang* ${ }^{P h D}{ }^{1}$, Xiao Dong $\mathrm{He}^{*} \mathrm{MD}^{2}$, Nan Yao MD${ }^{1}$, Wen Jia Liang $\mathrm{MSC}^{3}$, You Cheng Zhang MD PhD²
}

J Wang, XD He, N Yao, WJ Liang, YC Zhang. A meta-analysis of adjuvant therapy after potentially curative treatment for hepatocellular carcinoma. Can J Gastroenterol 2013;27(6): 351-363.

BACKGROUND: The high recurrence rate of hepatocellular carcinoma (HCC) after potentially curative treatment determines the long-term prognosis.

OBJECTIVE: To evaluate the efficacy and safety of adjuvant therapies in patients with HCC who have undergone hepatic resection, transplantation or locoregional ablation therapy.

METHODS: Several databases were searched to identify randomized controlled trials (RCTs) fulfilling the predefined selection criteria. Meta-analyses were performed to estimate the effects of adjuvant therapies of any modality on recurrence-free survival (RFS) and overall survival (OS).

RESULTS: Eight adjuvant modalities were identified from 27 eligible RCTs conducted predominantly in Asian populations comparing adjuvant with no adjuvant therapy. Adjuvant chemotherapy, internal radiation and heparanase inhibitor PI-88 therapy failed to improve RFS or OS, while interferon (IFN) therapy yielded significant survival results. The findings of adjuvant vitamin analogue therapy required further examination. Adjuvant adoptive immunotherapy conferred significant benefit for RFS but not for OS. Although cancer vaccine therapy and radioimmunotherapy may improve survival after radical surgery, the results were from single, small-scale trials. Severe side effects were observed in the studies of adjuvant chemotherapy and of IFN therapy.

CONCLUSIONS: Adjuvant IFN therapy can improve both RFS and OS; however, the benefits of using this agent should be weighed against its side effects. Combination of systemic and transhepatic arterial chemotherapy is not recommended for HCC after potentially curative treatment. Other adjuvant therapies produce limited success for survival. Additional RCTs with proper design are required to establish the role of adjuvant therapies for HCC.

Key Words: Adjuvant therapy; Hepatocellular carcinoma; Recurrence; Survival

XJorldwide, hepatocellular carcinoma (HCC), the most common W primary cancer of the liver, ranks sixth among malignant tumours in incidence and is the third leading cause of cancer-related death (1). In China, owing to the high prevalence of hepatitis B viral infection and associated liver cirrhosis, HCC accounts for $>54 \%$ of the world annual incidence, with an estimated 372,079 mortalities in $2008(1-3)$.

For many years, surgery (hepatic resection and transplantation) has been considered the only curative option for HCC. Locoregional ablation therapy, particularly percutaneous radiofrequency ablation (RFA), was recently demonstrated to have similar efficacy to surgical resection for small HCC nodules $(<3 \mathrm{~cm}$ in diameter) (4). Although these

\section{Une méta-analyse de la thérapie adjuvante après un traitement au potentiel curatif contre le carcinome hépatocellulaire}

HISTORIQUE : Le taux élevé de récurrence de carcinome hépatocellulaire $(\mathrm{CCH})$ après un traitement au potentiel curatif en détermine le pronostic à long terme.

OBJECTIF : Évaluer l'efficacité et l'innocuité des thérapies adjuvantes chez des patients atteints d'une $\mathrm{CCH}$ qui ont subi une résection hépatique, une transplantation ou une ablation locorégionale.

MÉTHODOLOGIE : Les auteurs ont fait des recherches dans plusieurs bases de données pour en extraire les essais aléatoires et contrôlés (EAC) qui respectaient les critères de sélection prédéfinis. Ils ont procédé à des méta-analyses pour évaluer les effets des thérapies adjuvantes, quelles que soient leurs modalités, sur la survie sans récurrence (SSR) et la survie globale (SG).

RÉSULTATS : Les chercheurs ont établi huit modalités tirées des 27 EAC admissibles menés surtout auprès de populations asiatiques, qui comparaient la thérapie adjuvante à l'absence de thérapie adjuvante. La chimiothérapie adjuvante, la radiation interne et la thérapie par inhibiteur de l'héparanase PI-88 n'amélioraient pas la SSR et la SG, mais la thérapie à l'interféron (IFN) donnait des résultats significatifs sur le plan de la survie. L'immunothérapie adjuvante adoptive avait d'importants avantages pour la SSR, mais par pour la SG. Même si la thérapie du cancer par la vaccination et la radio-immunothérapie peuvent accroître la survie après une chirurgie radicale, les résultats provenaient d'essais uniques à petite échelle. Les chercheurs ont observé des effets secondaires marqués dans les études sur la chimiothérapie adjuvante et la thérapie à l'IFN.

CONCLUSIONS : La thérapie à l'IFN adjuvante peut améliorer la SSR et la SG, mais il faudrait soupeser les avantages de cet agent par rapport à ses effets secondaires. Il n'est pas recommandé de dispenser une association de chimiothérapie systémique et artérielle transhépatique du $\mathrm{CCH}$ après un traitement au potentiel curatif. Les autres thérapies adjuvantes avaient peu de succès sur le plan de la survie. D'autres EAC bien conçus s'imposent pour établir le rôle des thérapiesadjuvantes du $\mathrm{CCH}$.

treatments offer a possibility of cure for HCC, the long-term outcomes after surgery or ablation therapy are disappointing because of the high frequency of recurrence. HCC often recurs as a result of intrahepatic dissemination of primary cancer cells or the development of a de novo tumour in the cirrhotic liver, which, in total, complicates $70 \%$ of cases at five years (5-7). However, because it is difficult to distinguish the two types of HCC recurrence in routine clinical practice, the presence of tumour originating from either primary or metachronous multicentric carcinogenesis is regarded as a recurrence (8). Therefore, adjuvant therapy that aims to reduce or delay the incidence of recurrence by eradicating the growth of pre-existing minute tumour foci not detected before initiation of adjuvant therapy, or by inhibiting the occurrence

\footnotetext{
*Co-First Authors. ${ }^{1}$ Department of General Surgery, The First Hospital of Lanzhou University; ${ }^{2}$ Department of General Surgery, Lanzhou University

Second Hospital; ${ }^{3}$ Department of Burn Surgery, People's Hospital of Gansu Province, Gansu, China

Correspondence: Dr You Cheng Zhang, Department of General Surgery, Lanzhou University Second Hospital, Lanzhou 730030, Gansu, China.

Telephone 86-931-894-2287, fax 86-931-845-8109, e-mail zhangychphd@yahoo.cn

Received for publication April 10, 2012. Accepted October 25, 2012
} 
of metachronous multicentric tumours, is essential to improve the efficacy of curative treatment of HCC.

Several adjuvant modalities have been developed in the past decades; nevertheless, the clinical use of these therapies is either controversial or requires further evaluation (9). To date, there have been five reviews or meta-analytic studies (10-14) published between 2002 and 2009 assessing the role of neoadjuvant and/or adjuvant therapy for HCC. While the early analyses (10-12) had achieved modest survival benefits from some adjuvant therapies, two recent studies with updated evidence $(13,14)$ only applied qualitative descriptive approaches for therapeutic evaluation. Furthermore, these studies $(10-14)$ neither considered modalities other than surgical resection as potentially curative treatment for HCC, nor quantitatively measured the effects of adjuvant therapies on survival using time-to-event outcomes. On the other hand, although previous individual meta-analyses have also shown encouraging results with adjuvant chemotherapy $(15,16)$, adjuvant immunotherapy (17-23) and vitamin analogue chemoprevention (24), some of these may be inconclusive or of doubtful accuracy because of bias due to limited sample size and statistical methodological flaws $(15,16,24)$. Nevertheless, emerging evidence from randomized controlled trials (RCTs) of novel adjuvant modalities and from trials with updated information is currently available. Given that no therapies after potentially curative treatments have been accepted as standard of care in HCC to date, the effects of adjuvant therapies on recurrence and survival are even less clear. Using currently available RCT evidence and knowledge of survival analysis (25-27), the aim of the present study was to evaluate the efficacy of adjuvant therapies of any modality in terms of the hazard ratio (HR) of recurrence-free survival (RFS) and overall survival (OS), and the safety of these adjuvant therapies after potentially curative treatment with surgical resection, liver transplantation or ablation therapy for HCC.

\section{METHODS}

Literature search

The Cochrane Library, MEDLINE (via PubMed) and Embase were searched using the keywords "hepatocellular carcinoma" and "recurrence". Both medical subject and text terms were used and combined, and the search strategy was not restricted to languages or publication date. However, only RCTs were considered in the present metaanalysis, for which searches in MEDLINE and Embase were limited by study type. The searches were performed mainly in June 2011, and the result was updated in November 2011. In addition, published metaanalyses and reviews of relevance were scrutinized for other potential studies, and reference lists of included trials were manually searched.

\section{Inclusion and exclusion criteria}

RCTs published as full text assessing adjuvant therapy in patients with HCC who had undergone potentially curative treatment with surgical resection, hepatic transplantation or locoregional ablation therapy were eligible if recurrence-related outcomes were analyzed using survival analysis. However, to guarantee that adjuvant therapy was truly adjuvant, only trials in which randomization was performed after patients had been treated with initially curative treatment were considered. Trials concurrently comparing sequential combinations of curative and adjuvant therapies versus curative treatment alone were excluded because adjuvant effects in such trials could not be separately evaluated due to the presence of initially curative treatment. Similarly, given the nature of neoadjuvant trials for which patient allocation is achieved before curative treatment, neoadjuvant therapy was not included in the present study. Furthermore, because no well-accepted adjuvant therapeutic modality has been currently established, the meta-analysis only compared adjuvant therapy with no active adjuvant therapy (no treatment or concurrent placebo). Other exclusions were trials with nonrandomized design, studies involving noncurative or palliative treatment for HCC, and trials comparing different adjuvant therapies or different schedules of one adjuvant therapy.
Study selection and outcomes measurement

All references records retrieved from the searches were stored in an EndNote (Thomson Reuters, USA) file and duplicates were removed. Two authors independently assessed eligibility against the inclusion criteria by scanning the title and abstract of each record, with disagreement resolved by discussion. Where studies had multiple publications, the most recent report was included and secondary articles were also considered. Trials containing three or more study groups were retained if at least two groups addressed an eligible comparison.

The primary outcome was RFS, which is also referred to as diseasefree survival (DFS). However, for studies in which neither of the two outcomes was reported, time to recurrence (TTR) was used as a surrogate outcome. The secondary outcomes were OS and side effects.

\section{Data extraction and analysis}

Information regarding adjuvant therapy protocols of each trial was extracted and tabulated, along with tumour histological factors (size, number and vascular invasion) and staging of HCC, and underlying liver disease, which are the variables that are the most important predictors of recurrence and survival (28-30). Details of methodological quality assessment of the included RCTs were also abstracted. The number of patients developing events (recurrence or death) during follow-up was recorded. Locations and types of recurrence, and reasons for death were also presented. Furthermore, to determine the risk of patients developing events, recurrence and survival rates at various time points (one, two, three, four and five years) for patients in the control group (did not receive an active adjuvant therapy) were reported.

The HR of time-to-event outcomes (ie, RFS, TTR and OS) was directly extracted from trial publication, if available, or was estimated indirectly using the reported number of events and the corresponding $\mathrm{P}$ value for the log-rank statistics, or by reading survival curves, as described by Parmar et al (25). An Excel spreadsheet (Microsoft, USA) developed by the Meta-analysis Group of the MRC Clinical Trials was used for the calculations (26).

A pooled analysis was performed for RCTs testing a similar modality of adjuvant therapy, for which all trials included were analyzed in several subgroups to assess their effects on RFS and OS. Sensitivity analyses were performed to examine effects of excluding extraordinary studies with either quality concerns or confounding data. In the safety analyses, however, because the criteria for assessment varied across trials, only side effects requiring a discontinuation of adjuvant therapy were reported. All outcomes data were extracted on worksheets and were cross-checked for accuracy by two authors before combining for analysis.

\section{Quality assessment}

The methodological quality of RCTs was assessed independently by two authors, using the criteria outlined in Cochrane Handbook for Systematic Reviews of Interventions (Version 5) (31). Any disagreement was resolved by discussion or by consulting a third author. Six items assessing components of internal validity of RCTs were applied: generation of random sequence, allocation concealment, completeness of outcomes data reporting, whether free of selective reporting, and other bias including whether balanced in baseline characteristics and whether there was a priori sample size calculation. Blinding was, however, removed in the assessment of risk of bias, given the impracticability to mask adjuvant therapy in most trials using no treatment as a comparator. Each item was scored as 'yes' for low risk of bias, 'unclear' for either lack of information or uncertainty over the potential for bias, and 'no' for high risk of bias.

\section{Statistical analysis}

Time-to-event outcomes were combined using the inverse variance method in Review Manager Software (Version 5.1.1, The Nordic Cochrane Centre, The Cochrane Collaboration) with a fixed-effect model. A pooled HR represents the overall risk of an event on adjuvant therapy over control, in which $\mathrm{HR}<1.0$ favoured adjuvant therapy and $\mathrm{HR} \geq 1.0$ favoured control. Respective 95\% CIs were calculated for each estimate. Statistical heterogeneity of the results of 


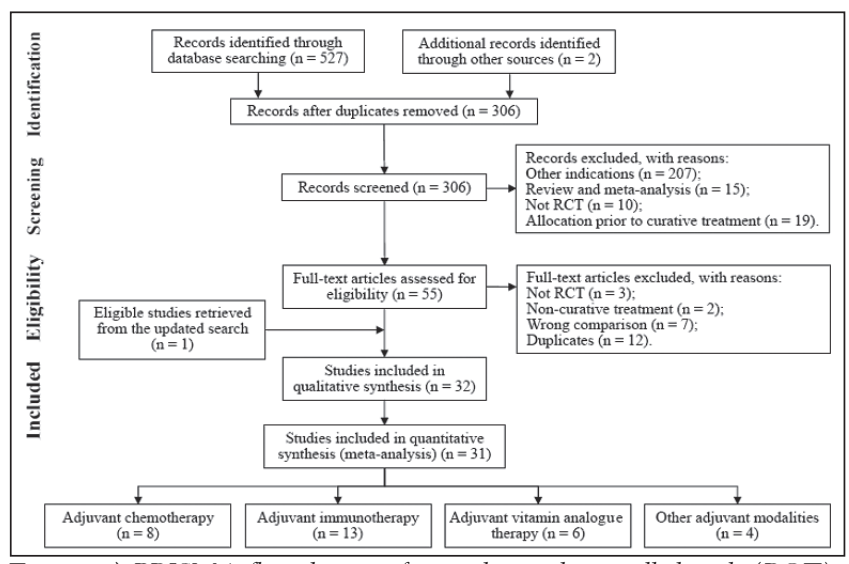

Figure 1) PRISMA flow diagram for randomized controlled trials (RCT)

the trials was assessed using the $\chi^{2}$ statistic and the proportion of variation due to heterogeneity was expressed as $\mathrm{I}^{2}$, where $\mathrm{I}^{2}<25 \%$ is considered to be low-level heterogeneity, $25 \%$ to $50 \%$ as moderate-level, and $\mathrm{I}^{2}>50 \%$ as high-level heterogeneity (32). Recurrence and survival rates were expressed as median values with the minimum to maximum range.

\section{RESULTS}

Search results and characteristics of the included RCTs

The databases searches indentified 527 records, and another two were obtained from references lists. Of these, 474 were initially judged as irrelevant, yielding 55 potential study reports that were assessed for eligibility at full-text level, resulting in retrieval of another prospective trial. Finally, 32 publications corresponding to 28 RCTs met the inclusion criteria, from which 31 publications (33-63) of 27 trials, involving a total of 2614 randomized patients, were eligible for analysis (one study [64] was excluded due to insufficient reporting of survival outcomes data). Figure 1 summarizes the study identification flow according to the recommendations of the PRISMA statement (65).

From the 31 trial publications assessing adjuvant therapy, eight modalities were indentified, including chemotherapy in eight (three [33-35] involved oral, three [36-38] transhepatic arterial and two $[39,40]$ a combination of systemic and transhepatic arterial approaches), interferon (IFN) therapy in nine (eight [42-49] used IFN- $\alpha$ and one [41] IFN- $\beta$ ), vitamin analogue therapy in six (two $[50,51]$ tested polyprenoic acid, a vitamin A [VA] analogue; and four [52-55] menatetrenone, a vitamin $\mathrm{K} 2$ [VK2] analogue), adoptive immunotherapy in three (one [56] involved lymphokine-activated killer [LAK] and two [57,58] cytokine-induced killer [CIK] cells), cancer vaccine therapy with autologous HCC fragments in one (59), internal radiation therapy using transhepatic arterial infusion of iodine 131-labelled lipiodol ( ${ }^{131}$ I-lipiodol) in two $(60,61)$, antibody-targeted radioimmunotherapy with ${ }^{131}$ I-lipiodol metuximab (Licartin, Chengdu Hoist Hitech Co. Ltd, China; and the Fourth Military Medical University, Xi'an, China) in one (62), and molecular targeted therapy with heparanase inhibitor PI-88 in one study (63) (Table 1). Most of the trials were conducted or presented in the past decade, and all except one (47) were performed among Asian populations (Japan and China). The sample size of the RCTs varied from 15 (38) to 548 (55), and the range of median followup duration was between $12.3(62)$ and 66 (61) months. Randomization was done after curative treatment for HCC in all of these adjuvant trials, and the delay between curative and the first adjuvant therapy was usually scheduled to commence after one month. Of the RCTs included, 24 trials compared adjuvant therapy with no active adjuvant therapy, while the other three $(50,55,62)$ used a concurrent control group involving placebo.

With regard to modes of initially curative treatment, 26 RCTs used hepatic resection, or locoregional ablation therapy (percutaneous
TABLE 1

General information regarding the included studies

\begin{tabular}{lc}
\hline & RCTs (publications), \\
$\mathbf{n}(\mathbf{n})$
\end{tabular}

*Two reports from one trial were presented in 1999 and in 2008, respectively; †Includes ablation therapy with or without transhepatic arterial therapy; ${ }^{\ddagger}$ In terms of patients analyzed; ' One study reported time to second primary hepatocellular carcinoma; "According to presented recurrence curves. RCT Randomized controlled trial

ethanol/acetic acid injection or RFA) given with or without transarterial chemoembolization, while the remaining RCT (62) involved liver transplantation. Nevertheless, among the individual trials in which surgical resection or ablation therapy was used as initial treatment for HCC $(41,50,52-55)$, the proportion of patients receiving either of the treatments was balanced between the compared groups. Curative treatment was performed for primary HCC in all trials except for one (55), in which $21 \%$ of the enrolled patients had undergone hepatic resection or ablation therapy for their first intrahepatic recurrence of HCC. Of the $27 \mathrm{RCT}$, 22 (33,35-37,39,40,44-50,52-54,56$59,61,63)$ specified curativity of initial treatment, which was usually on the basis of defining a completed tumour-eliminating surgical or ablation procedure and/or identifying a postprocedural imaging findings indicative of no demonstrable residual tumour.

The searches identified three publications of one trial by Kubo et al and others (42-44). Although the latest report (44) provided final outcomes data, the previous two publications $(42,43)$ were also considered for analysis because they reported other important information of the trial accrual. The polyprenoic acid study by Muto et al $(50,51)$ and internal radiation study by Lau et al $(60,61)$ also presented two 
TABLE 2

Summary of study results regarding recurrence and survival

\begin{tabular}{|c|c|c|c|c|c|c|c|c|c|c|c|c|c|c|}
\hline \multirow[b]{3}{*}{ Study* (reference) } & \multicolumn{9}{|c|}{ Recurrence } & \multirow{2}{*}{\multicolumn{5}{|c|}{$\begin{array}{c}\text { Survival } \\
\text { Survival rates for patients } \\
\text { without adjuvant therapy, } \%\end{array}$}} \\
\hline & \multirow{2}{*}{$\begin{array}{c}\text { Overall } \\
\text { recurrence, } \\
\mathbf{n}\end{array}$} & \multirow{2}{*}{$\begin{array}{c}\text { Intrahepatic } \\
\text { recurrence, \% }\end{array}$} & \multicolumn{5}{|c|}{$\begin{array}{l}\text { Recurrence rates for patients without } \\
\text { adjuvant therapy, \% }\end{array}$} & \multirow{2}{*}{$\begin{array}{l}\text { Overall } \\
\text { death, } n\end{array}$} & \multirow{2}{*}{$\begin{array}{l}\text { Death due to } \\
\text { recurrence, \% }\end{array}$} & & & & & \\
\hline & & & 1-year & 2-year & 3-year & 4-year & 5-year & & & 1-year & 2-year & 3-year & 4-year & 5-year \\
\hline Yamamoto et al (33) & 35 & 83 & 28 & 48 & 66 & 71 & 82 & 22 & 68 & 82 & 78 & 67 & 52 & 48 \\
\hline Ono et al (40) & 38 & 97 & 19 & 30 & 59 & 71 & 84 & 23 & 83 & 92 & 81 & 77 & 56 & 56 \\
\hline Ueno et al (37) & NA & NA & 56 & 78 & NA & NA & NA & NA & NA & NA & NA & NA & NA & NA \\
\hline Lau et al $(60,61)$ & 24 & 88 & 41 & 64 & 64 & 68 & 68 & 26 & 81 & 86 & 62 & 46 & 36 & 36 \\
\hline Ikeda et al (41) & 8 & NA & 63 & 100 & NA & NA & NA & $0^{\ddagger}$ & NA & NA & NA & NA & NA & NA \\
\hline Takayama et al (56) & 102 & 90 & 40 & 55 & 67 & 73 & 78 & 52 & 92 & 95 & 85 & 74 & 68 & 62 \\
\hline Kubo et al (42-44) & 22 & 100 & 19 & 47 & 74 & 80 & 87 & 12 & 100 & 94 & 87 & 80 & 58 & 47 \\
\hline Tanaka et al (38) & NA & NA & 63 & 88 & NA & NA & NA & NA & NA & 75 & 25 & 25 & NA & NA \\
\hline Hasegawa et al (34) & 115 & NA & 29 & 38 & 63 & 66 & 71 & NA & NA & 99 & 98 & 92 & 83 & 73 \\
\hline Sun et al (48) & 138 & 87 & 42 & 54 & 60 & 65 & 65 & 98 & 92 & 78 & 62 & 52 & 44 & 44 \\
\hline Mazzaferro et al (47) & 100 & NA & 34 & 51 & 63 & 77 & 94 & 61 & 67 & NA & NA & NA & NA & NA \\
\hline Mizuta et al (52) & 40 & NA & 55 & 83 & 92 & NA & NA & 11 & 73 & 96 & 81 & 64 & NA & NA \\
\hline Lo et al (49) & 43 & 79 & 30 & 45 & 50 & 53 & 55 & 21 & 76 & 85 & 72 & 70 & 70 & 61 \\
\hline Hotta et al (53) & 19 & NA & 33 & 47 & 73 & NA & NA & NA & NA & 88 & 82 & 82 & NA & NA \\
\hline Kakizaki et al (54) & 34 & NA & 28 & 64 & 90 & NA & NA & 11 & 82 & 96 & 90 & 66 & NA & NA \\
\hline Xu et al (62) & 25 & 32 & 57 & NA & NA & NA & NA & 15 & NA & 62 & NA & NA & NA & NA \\
\hline Weng et al (57) & 46 & 93 & 30 & NA & NA & NA & NA & $0^{\ddagger}$ & NA & NA & NA & NA & NA & NA \\
\hline
\end{tabular}

${ }^{*}$ Listed according to year of publication; ${ }^{\dagger}$ Recurrence rate of second primary hepatocellular carcinoma; ${ }^{\ddagger}$ No patients died during follow-up. NA Not available.

unduplicated articles; hence, data from both reports of each of the studies were used, separately $(50,51)$ or in combination $(60,61)$, in the outcomes analysis. Six RCTs $(33,46,49,55,58,59)$ involved three or more study groups. In two of these $(46,55)$, because no difference in recurrence rates and in RFS was found between two adjuvant groups, respectively, data from both adjuvant groups were combined for analysis. However, for the other four trials $(33,49,59,63)$, due to the lack of combined outcomes data, only selected adjuvant groups were compared with control. The HR of RFS, TTR or OS was estimated using indirect methods $(25,26)$ for most of the RCTs, because only a few studies $(34,35,55,59)$ directly provided data for these time-to-event outcomes.

Overall, 13 trials $(33,35-37,46,49,50,52,54,56-59)$ found adjuvant therapy could confer a significant advantage in RFS or TTR, and six $(38,44,48,51,59,62)$ indentified a significant OS gain with adjuvant therapy. In four other trials $(34,39,40,55)$, however, adjuvant therapy demonstrated worse outcomes compared with no adjuvant therapy, although differences in RFS or OS were insignificant.

Summary of study results on recurrence and survival

A total of 1151 patients from both adjuvant and control groups of 24 trials (33-36,39-41,44,46-50,52-59,61-63) reported recurrence of HCC during follow-up, and the proportion of intrahepatic recurrence among 14 studies $(33,35,36,39,40,44,48,49,55-59,61)$ was in the range of $79 \%(49)$ to $100 \%$ (44) (Table 2). In the only trial involving liver transplantation as initial curative treatment (62), more patients developing extrahepatic recurrence were observed (68\%). With regard to types of recurrence, although most of the studies failed to specify the distinction between intrahepatic metastasis and de novo tumour for recurrent disease, it was noteworthy the incidence of second primary HCC characterized by multicentric carcinogenesis in the only study $(50,51)$ was $79 \%$ (27 of 34 recurrences). Of 525 deaths noted from 18 RCTs $(33,35,36,39,40,44-49,52,54,56,58,59,61,62)$, $67 \%(47)$ to $100 \%(44,45,59)$ of cases were the result of recurrent HCC that occurred predominantly in residual liver.

As illustrated in Table 2, for patients receiving no active adjuvant therapy after potentially curative treatment for HCC, the median one-, two-, three-, four- and five-year recurrence rates were $36 \%$ (range $17 \%$ to $68 \%$ ), $58 \%$ (range $30 \%$ to $100 \%$ ), 69\% (range $50 \%$ to $92 \%$ ), $73 \%$ (range $52 \%$ to $94 \%$ ) and $82 \%$ (range $55 \%$ to $94 \%$ ), respectively; and that for survival rates at the corresponding time point were $88 \%$ (range $62 \%$ to $99 \%$ ), $81 \%$ (range $25 \%$ to $98 \%$ ), $67 \%$ (range $25 \%$ to $92 \%$ ), $57 \%$ (range $36 \%$ to $83 \%$ ) and $48 \%$ (range $29 \%$ to $73 \%$ ), respectively.

Efficacy and safety evaluation of adjuvant therapy

For assessment and analysis of adjuvant therapies for which there was potential for clinical benefit, these 27 RCTs were classified into five categories: chemotherapy, IFN therapy, vitamin analogue therapy, adoptive immunotherapy and other therapies (each therapy was tested in a single trial) including cancer vaccine therapy, internal radiation therapy, radioimmunotherapy and heparanase inhibitor PI-88 therapy. A detailed description of treatment protocols, study characteristics and methodological quality assessment of the RCTs are presented in Tables 3 to 12 . 
TABLE 3

Characteristics of the randomized controlled trials evaluating adjuvant chemotherapy

\begin{tabular}{|c|c|c|c|c|}
\hline \multirow[b]{2}{*}{ Study (reference) } & \multirow[b]{2}{*}{ Adjuvant protocol and number of patients } & \multicolumn{3}{|c|}{ Patients' baseline characteristics } \\
\hline & & Tumour characteristics & Liver disease & Follow-up \\
\hline \multicolumn{5}{|l|}{ Oral chemotherapy } \\
\hline \multirow[t]{2}{*}{$\begin{array}{l}\text { Yamamoto et al } \\
\text { (33) }\end{array}$} & $\begin{array}{l}\text { Study arm: oral HCFC } 200 \text { mg twice daily until recurrence or } \\
\text { severe side effects developed; } n=35\end{array}$ & UICC stage II & $\begin{array}{l}\text { LCSGJ stage } \\
\text { I-II; cirrhosis }\end{array}$ & NR \\
\hline & Control arm: no adjuvant therapy; $n=32$ & & $65 \%$ & \\
\hline Hasegawa et al (34) & $\begin{array}{l}\text { Study arm: oral UFT } 300 \text { mg/day for } 1 \text { year; } n=79 \\
\text { Control arm: no adjuvant therapy; } n=80\end{array}$ & $\begin{array}{l}\text { Single nodule } 70 \% \text {; median tumour size } \\
33 \mathrm{~mm} \text { for study arm and } 34 \mathrm{~mm} \text { for } \\
\text { control arm; vascular invasion } 22 \%\end{array}$ & $\begin{array}{l}\text { C-P A } 87 \% \\
\text { cirrhosis } 50 \%\end{array}$ & $\begin{array}{l}\text { Median } \\
4.8 \text { years }\end{array}$ \\
\hline Xia et al (35) & $\begin{array}{l}\text { Study arm: oral CAP } 1000 \mathrm{mg} / \mathrm{m}^{2} \text { twice daily for } 4-6 \text { courses } \\
\text { ( } 1 \text { course consisted of } 2 \text { weeks of CAP followed by a } 1 \text {-week } \\
\text { interval); } n=30\end{array}$ & $\begin{array}{l}\text { pTNM stage I-III; single nodule } 70 \% \text {; } \\
\text { tumour size }>5 \mathrm{~cm} 57 \% \text {; microvessels } \\
\text { invasion } 63 \%\end{array}$ & $\begin{array}{l}\text { C-P A } 100 \% \\
\text { cirrhosis } 33 \%\end{array}$ & $\begin{array}{l}\text { Median } \\
47.5 \text { months }\end{array}$ \\
\hline
\end{tabular}

Transhepatic arterial chemotherapy

Control arm: no adjuvant therapy; $n=30$

Izumi et al (36) Study arm: L-TAC (ADM $20 \mathrm{mg} / \mathrm{m}^{2}+\mathrm{MMC} 10 \mathrm{mg} / \mathrm{m}^{2}$ ) with or without embolization once; $n=23$

Control arm: no adjuvant therapy; $n=27$

Tumour size >5 cm 76\%; vascular inva- Cirrhosis $82 \% \quad$ NR sion and/or intrahepatic metastasis $100 \%$

Ueno et al (37) Study arm: TAC (CDDP 50-80 mg/body + MMC 10 mg/body) 2-3 times (1-month intervals); $n=10$

NR NR NR

Control arm: no adjuvant therapy; $n=11$

Tanaka et al (38) Study arm: TAC (CDDP $10 \mathrm{mg}+5$-FU $250 \mathrm{mg}$ ) for 4 courses

(one course consisted of daily TAC for 5 consecutive days and a 2-day interval); $n=7$

Control arm: no adjuvant therapy; $n=8$

Systemic and transhepatic arterial chemotherapy

Lai et al (39) Study arm: L-TAC (CDDP $10 \mathrm{mg}) 3$ times (2-month intervals), and iv EPI $40 \mathrm{mg} / \mathrm{m}^{2}, 8$ doses (6-week intervals); $\mathrm{n}=30$

Control arm: no adjuvant therapy; $n=36$

Ono et al (40) Study arm: TAC (EPI $40 \mathrm{mg} / \mathrm{m}^{2}$ ) once, followed by iv EPI $40 \mathrm{mg} / \mathrm{m}^{2}$ (3-month interval) and daily oral HCFC 300 mg/day for 2 years; $\mathrm{n}=29$

Control arm: no adjuvant therapy; $\mathrm{n}=27$

Portal vein invasion and/or intrahepatic NR

NR metastasis $100 \%$

(1)
LCSGJ stage I-III; single nodule 60\%; Cirrhosis 55\% Median tumour size $>5 \mathrm{~cm} 65 \%$; vascular inva- 28.3 months sion $45 \%$

Mean tumour number 4.2 for study arm
and 3.7 for control arm; Mean tumour
size $1.4 \mathrm{~cm}$ for study arm and $1.2 \mathrm{~cm}$ size $1.4 \mathrm{~cm}$ for study arm and $1.2 \mathrm{~cm}$
for control arm vascular invasion $34 \%$

C-P A 75\%; NR cirrhosis $68 \%$

5-FU 5-Fluorouracil; ADM Adramycin (doxorubicin); CAP Capecitabine; CDDP Cisplatin; C-P Child-Pugh class; EPI Epirubicin; HCFC 1-hexylcarbamoyl-5-fluorouracil (carmofur); iv Intravenous; LCSGJ Liver Cancer Study Group of Japan; L-TAC Transarterial chemotherapy and lipiodolization; MMC Mitomycin c; NR Not reported; pTNM Pathological tumour-node metastasis; TAC Transarterial chemotherapy; UFT Uracil-tegafur; UICC Union for International Cancer Control

\section{RFS}

The outcome of RFS or DFS was reported in 18 trials (33-40,44,47-49, $55-59,61)$, four $(35,56,57,59)$ of which also included TTR as a primary outcome. However, for the other nine trials $(41,45,46,50,52-54,62,63)$ that reported recurrence or recurrence-free rates, TTR was used as surrogate outcome. Eight subgroup analyses were performed for RFS (Figure 2).

Chemotherapy: The meta-analysis for eight trials (33-40) demonstrated that adjuvant chemotherapy failed to improve RFS compared with no treatment (HR 0.94 [95\% CI 0.81 to 1.10]). Nevertheless, a significant statistical heterogeneity among the trials was found $\left(\mathrm{I}^{2}=55 \%\right)$. After excluding any of these eight trials by sensitivity analysis, heterogeneity was consistently high (data not shown). Therefore, the eight trials were further subdivided according to the different administration routes of chemotherapy (Figure 3), and the results showed that adjuvant oral chemotherapy (HR 0.91 [95\% CI 0.77 to 1.09$] ; \mathrm{I}^{2}=77 \%$ ) and transhepatic arterial chemotherapy (HR 0.69 [95\% CI 0.41 to 1.16$] ; \mathrm{I}^{2}=0 \%$ ) did not improve RFS, while the pooled HR for two trials $(39,40)$ testing the combination of systemic and transhepatic arterial chemotherapy marginally favoured no adjuvant therapy (HR 1.51 [95\% CI 0.94 to 2.40$] ; \mathrm{I}^{2}=11 \%$ ).

IFN therapy: Seven RCTs (41-49) of adjuvant IFN therapy were pooled for RFS, and the result favoured IFN therapy (HR 0.72 [95\% CI 0.59 to 0.88 ; data not shown) but with an obvious heterogeneity
$\left(\mathrm{I}^{2}=60 \%\right)$. After carefully examining the characteristics of each trial, the RCT by Ikeda et al (41) appeared to be the source of the heterogeneity. This was the only trial identified that used IFN- $\beta$, and the sample sizes were small (10 patients each in IFN and control groups); it was also restricted by methodological limitations. The sensitivity analysis excluding the study (41) showed that pooled HR was 0.75 (95\% CI 0.61 to 0.92; Figure 2), significantly favouring adjuvant IFN therapy with acceptable heterogeneity $\left(\mathrm{I}^{2}=5 \%\right)$.

Vitamin analogue therapy: The pooled analysis for five trials testing polyprenoic acid $(50,51)$ or menatetrenone $(52-55)$ indentified a significant RFS gain with these vitamin analogues (HR $0.76[95 \% \mathrm{CI}$ 0.60 to 0.96 ]; data not shown). However, an elevated heterogeneity was observed across the studies $\left(I^{2}=78 \%\right)$, which was likely due to the inclusion of the VK2 study by Yoshida et al (55). Despite having the largest sample size $(n=548)$, this trial (55) enrolled $21 \%$ patients with first intrahepatic recurrence of HCC and was terminated after a maximum follow-up of only 36 months, all of which may confound the combined result. Nevertheless, restricting the analysis to the other four RCTs (50-54) did not change the effects of adjuvant vitamin analogue therapy on RFS (HR 0.43 [95\% CI 0.30 to 0.62]; Figure 2), while heterogeneity was eliminated $\left(\mathrm{I}^{2}=0 \%\right)$.

Adoptive immunotherapy: The meta-analysis of RFS for the three RCTs (56-58) showed a significant difference favouring adoptive immunotherapy, compared with no adjuvant therapy (HR $0.55[95 \%$ 
TABLE 4

Methodological quality assessment of the randomized controlled trials evaluating adjuvant chemotherapy

\begin{tabular}{|c|c|c|c|c|c|c|}
\hline \multirow[b]{2}{*}{$\begin{array}{l}\text { Study } \\
\text { (reference) }\end{array}$} & \multirow[b]{2}{*}{$\begin{array}{c}\text { Random sequence } \\
\text { generation }\end{array}$} & \multirow[b]{2}{*}{ Allocation concealment } & \multirow[b]{2}{*}{$\begin{array}{l}\text { Incomplete } \\
\text { outcome data }\end{array}$} & \multirow[b]{2}{*}{ Selective reporting } & \multicolumn{2}{|c|}{ Other bias } \\
\hline & & & & & $\begin{array}{c}\text { Balanced in } \\
\text { baseline } \\
\text { characteristics }\end{array}$ & $\begin{array}{c}\text { Sample size } \\
\text { calculation }\end{array}$ \\
\hline $\begin{array}{l}\text { Yamamoto et al } \\
\text { (33) }\end{array}$ & $\begin{array}{l}\text { Unclear: only stated } \\
\text { as random }\end{array}$ & $\begin{array}{l}\text { Yes: by central office } \\
\text { telephone }\end{array}$ & Yes: analysis by ITT & $\begin{array}{l}\text { Unclear: the study protocol was } \\
\text { unavailable }\end{array}$ & Yes & No \\
\hline $\begin{array}{l}\text { Hasegawa et al } \\
\text { (34) }\end{array}$ & $\begin{array}{l}\text { Yes: minimization } \\
\text { randomization }\end{array}$ & $\begin{array}{l}\text { Unclear: by an independent } \\
\text { investigator }\end{array}$ & $\begin{array}{l}\text { Unclear: ITT analysis } \\
\text { excluded } 1 \text { patient } \\
\text { randomly assigned to } \\
\text { the treatment arm }\end{array}$ & $\begin{array}{l}\text { Yes: all expected outcomes } \\
\text { were reported in accordance } \\
\text { with the study protocol }\end{array}$ & Yes & Yes \\
\hline Xia et al (35) & $\begin{array}{l}\text { Unclear: only stated } \\
\text { as random }\end{array}$ & $\begin{array}{l}\text { Unclear: unspecified sealed } \\
\text { envelope procedure }\end{array}$ & Yes: analysis by ITT & $\begin{array}{l}\text { Unclear: the study protocol was } \\
\text { unavailable }\end{array}$ & Yes & No \\
\hline Izumi et al (36) & $\begin{array}{l}\text { Unclear: only stated } \\
\text { as random }\end{array}$ & $\begin{array}{l}\text { Unclear: only stated as } \\
\text { random }\end{array}$ & $\begin{array}{l}\text { Unclear: } 2 \text { patients } \\
\text { dropped out of the } \\
\text { treatment arm were } \\
\text { reported, but not } \\
\text { resolved }\end{array}$ & $\begin{array}{l}\text { Unclear: the study protocol was } \\
\text { unavailable }\end{array}$ & Yes & No \\
\hline Ueno et al (37) & $\begin{array}{l}\text { Unclear: unspecified } \\
\text { block randomiza- } \\
\text { tion }\end{array}$ & $\begin{array}{l}\text { Unclear: unspecified sealed } \\
\text { envelope procedure }\end{array}$ & Yes: analysis by ITT & $\begin{array}{l}\text { Unclear: the study protocol was } \\
\text { unavailable }\end{array}$ & Yes & No \\
\hline $\begin{array}{l}\text { Tanaka et al } \\
\text { (38) }\end{array}$ & $\begin{array}{l}\text { Unclear: only stated } \\
\text { as random }\end{array}$ & $\begin{array}{l}\text { Unclear: only stated as } \\
\text { random }\end{array}$ & Yes: analysis by ITT & $\begin{array}{l}\text { Unclear: the study protocol was } \\
\text { unavailable }\end{array}$ & Yes & No \\
\hline Lai et al (39) & $\begin{array}{l}\text { Unclear: only stated } \\
\text { as random }\end{array}$ & $\begin{array}{l}\text { Unclear: only stated as } \\
\text { random }\end{array}$ & Yes: analysis by ITT & $\begin{array}{l}\text { Unclear: the study protocol was } \\
\text { unavailable }\end{array}$ & Yes & Yes \\
\hline Ono et al (40) & $\begin{array}{l}\text { Unclear: only stated } \\
\text { as random }\end{array}$ & $\begin{array}{l}\text { Unclear: unspecified sealed } \\
\text { envelope procedure }\end{array}$ & Yes: analysis by ITT & $\begin{array}{l}\text { Unclear: the study protocol was } \\
\text { unavailable }\end{array}$ & Yes & No \\
\hline
\end{tabular}

ITT Intention-to-treat

\section{TABLE 5}

\section{Characteristics of the randomized controlled trials evaluating adjuvant interferon therapy}

\begin{tabular}{|c|c|c|c|c|}
\hline \multirow{2}{*}{$\begin{array}{l}\text { Study } \\
\text { (reference) }\end{array}$} & \multirow[b]{2}{*}{ Adjuvant protocol and number of patients } & \multicolumn{2}{|c|}{ Patients' baseline characteristics } & \multirow[b]{2}{*}{ Follow-up } \\
\hline & & Tumour characteristics & Liver disease & \\
\hline Ikeda et al (41) & $\begin{array}{l}\text { Study arm: IFN- } \beta 6 \text { MU twice a week for } 36 \text { months; } \\
n=10 \\
\text { Control arm: no adjuvant therapy; } n=10\end{array}$ & $\begin{array}{l}\text { Single nodule } 90 \% \text {; median tumour size } \\
22 \mathrm{~mm} \text { for study arm and } 20 \mathrm{~mm} \text { for } \\
\text { control arm; vascular invasion } 0 \%\end{array}$ & HCV 100\%; cirrhosis 85\% & Median 25 month \\
\hline $\begin{array}{c}\text { Kubo et al } \\
(42-44)\end{array}$ & $\begin{array}{l}\text { Study arm: daily IFN- } \alpha 6 \mathrm{MU} \text { for } 2 \text { weeks, then three } \\
\text { times per week for } 14 \text { weeks, followed by twice } \\
\text { weekly for } 88 \text { weeks; } n=15 \\
\text { Control arm: no adjuvant therapy; } n=15\end{array}$ & $\begin{array}{l}\text { Single tumour } 100 \% \text {; tumour size } \leq 5 \mathrm{~cm} \\
100 \%\end{array}$ & $\begin{array}{l}\text { HCV 100\%; C-P A 77\%; } \\
\text { cirrhosis 50\% }\end{array}$ & $\begin{array}{l}5.0 \text { years for study } \\
\text { arm and } 4.1 \text { years } \\
\text { for control arm }\end{array}$ \\
\hline $\begin{array}{l}\text { Shiratori et al } \\
(45)\end{array}$ & $\begin{array}{l}\text { Study arm: IFN- } \alpha 6 \text { MU three times a week for } \\
48 \text { months; } n=49 \\
\text { Control arm: no adjuvant therapy; } n=25\end{array}$ & $\begin{array}{l}\text { Single tumour } 65 \% \text {; tumour size } \leq 30 \mathrm{~mm} \\
100 \%\end{array}$ & $\begin{array}{l}\text { HCV 100\%; C-P A 100\%; } \\
\text { cirrhosis } 100 \%\end{array}$ & Mean 7.1 years \\
\hline Lin et al (46) & $\begin{array}{l}\text { Study arm 1: IFN- } \alpha 3 \text { MU thrice a week for } \\
24 \text { months; } n=11\end{array}$ & $\begin{array}{l}\text { Single tumour 83\%; median tumour size } \\
20-25 \mathrm{~mm}\end{array}$ & $\begin{array}{l}\text { HBV 53\%; C-P A 87\%; } \\
\text { cirrhosis 93\% }\end{array}$ & Median 27 months \\
\hline
\end{tabular}

Study arm 2: IFN-a 3 MU 10 times a month for

6 months, followed by $3 \mathrm{MU} 10$ times every

3 months for 18 months; $n=9$

Control arm: no adjuvant therapy; $\mathrm{n}=10$

Mazzaferro Study arm: IFN-a-2b 3 MU thrice a week for

et al (47) 48 weeks; $n=76$

Control arm: no adjuvant therapy; $n=74$

Sun et al (48) Study arm: IFN- -1 -1b 3 MU twice a week for two weeks, followed by $5 \mathrm{MU}$ thrice a week for 18 months; $n=118$

Control arm: no adjuvant therapy; $\mathrm{n}=118$

Lo et al (49) Study arm 1: IFN- $a-2 b 10 \mathrm{MU}$ three times per week for 16 months; $n=40$

Study arm 2: IFN- $a-2 b 30 \mathrm{MU}$ three times per week for 16 months; $n=6$

Control arm: no adjuvant therapy; $\mathrm{n}=40$
pTNM stage III-IV 39\%; single tumour 76\%; median tumour size $35 \mathrm{~mm}$; vascular invasion $21 \%$

Single tumour $87 \%$; tumor size $\leq 5 \mathrm{~cm} \quad$ HBV 100\%; cirrhosis $86 \%$ $69 \%$; microvessel invasion $76 \%$

HCV 100\%; C-P A 93\%; cirrhosis $100 \%$

Median 45 months

pTNM stage III-IVA 51\%; single tumour HBV 91\%; cirrhosis 50\% 79\%; Tumour size >5 cm 51\%;

vascular invasion $44 \%$
Median 36.5

months

30-71 months

C-P Child Child-Pugh class; HBV Hepatitis B virus; HCV Hepatitis C virus; IFN Interferon; MU Million units; pTNM Pathological tumour-node-metastasis 
TABLE 6

Methodological quality assessment of the randomized controlled trials evaluating adjuvant interferon therapy

\begin{tabular}{|c|c|c|c|c|c|c|}
\hline \multirow[b]{2}{*}{ Study (reference) } & \multirow[b]{2}{*}{$\begin{array}{c}\text { Random sequence } \\
\text { generation }\end{array}$} & \multirow[b]{2}{*}{ Allocation concealment } & \multirow[b]{2}{*}{$\begin{array}{c}\text { Incomplete } \\
\text { outcome data }\end{array}$} & \multirow[b]{2}{*}{ Selective reporting } & \multicolumn{2}{|c|}{ Other bias } \\
\hline & & & & & $\begin{array}{l}\text { Balanced in base- } \\
\text { line characteristics }\end{array}$ & $\begin{array}{c}\text { Sample size } \\
\text { calculation }\end{array}$ \\
\hline Ikeda et al (41) & $\begin{array}{l}\text { Unclear: only stated } \\
\text { as random }\end{array}$ & $\begin{array}{l}\text { Unclear: only stated as } \\
\text { random }\end{array}$ & Yes: analysis by ITT & $\begin{array}{l}\text { Unclear: the study protocol } \\
\text { was unavailable }\end{array}$ & Yes & No \\
\hline Kubo et al (42-44) & $\begin{array}{l}\text { Yes: from a random- } \\
\text { numbers table }\end{array}$ & $\begin{array}{l}\text { Unclear: assignments } \\
\text { were withheld from the } \\
\text { investigators }\end{array}$ & Yes: analysis by ITT & $\begin{array}{l}\text { Unclear: the study protocol } \\
\text { was unavailable }\end{array}$ & Yes & Yes \\
\hline Shiratori et al (45) & $\begin{array}{l}\text { Unclear: from an } \\
\text { unspecified } \\
\text { random list (2:1 } \\
\text { assignment ratio) }\end{array}$ & $\begin{array}{l}\text { Unclear: by an independent } \\
\text { investigator }\end{array}$ & Yes: analysis by ITT & $\begin{array}{l}\text { Unclear: the study protocol } \\
\text { was unavailable }\end{array}$ & Yes & Yes \\
\hline Lin et al (46) & $\begin{array}{l}\text { Unclear: only stated } \\
\text { as random }\end{array}$ & $\begin{array}{l}\text { Unclear: only stated as } \\
\text { random }\end{array}$ & Yes: analysis by ITT & $\begin{array}{l}\text { Unclear: the study protocol } \\
\text { was unavailable }\end{array}$ & Yes & No \\
\hline Mazzaferro et al (47) & $\begin{array}{l}\text { Yes: computer- } \\
\text { generated random } \\
\text { number }\end{array}$ & $\begin{array}{l}\text { Yes: by central office } \\
\text { telephone }\end{array}$ & $\begin{array}{l}\text { Unclear: ITT analysis } \\
\text { excluded } 1 \text { patient } \\
\text { randomized to the } \\
\text { treatment arm }\end{array}$ & $\begin{array}{l}\text { Yes: all expected } \\
\text { outcomes were reported } \\
\text { in accordance with the } \\
\text { study protocol }\end{array}$ & Yes & Yes \\
\hline Sun et al (48) & $\begin{array}{l}\text { Yes: computer- } \\
\text { generated random } \\
\text { number }\end{array}$ & $\begin{array}{l}\text { Unclear: unspecified } \\
\text { sealed envelope } \\
\text { procedure }\end{array}$ & Yes: analysis by ITT & $\begin{array}{l}\text { Unclear: the study protocol } \\
\text { was unavailable }\end{array}$ & Yes & Yes \\
\hline Lo et al (49) & $\begin{array}{l}\text { Unclear: only stated } \\
\text { as random }\end{array}$ & $\begin{array}{l}\text { Yes: sealed envelope } \\
\text { procedure, ensured by a } \\
\text { research assistant }\end{array}$ & Yes: analysis by ITT & $\begin{array}{l}\text { Unclear: the study protocol } \\
\text { was unavailable }\end{array}$ & Yes & Yes \\
\hline
\end{tabular}

ITT Intention-to-treat

TABLE 7

Characteristics of the randomized controlled trials evaluating adjuvant vitamin analogue therapy

\begin{tabular}{|c|c|c|c|c|}
\hline \multirow[b]{2}{*}{ Study (reference) } & \multirow[b]{2}{*}{ Adjuvant protocol and number of patients } & \multicolumn{2}{|l|}{ Patients' baseline characteristics } & \multirow[b]{2}{*}{ Follow-up } \\
\hline & & Tumour characteristics & Liver disease & \\
\hline \multicolumn{5}{|l|}{ Vitamin $A$ analogue } \\
\hline Muto et al $(50,51)$ & $\begin{array}{l}\text { Study arm: oral polyprenoic acid } 600 \mathrm{mg} / \text { day for } \\
12 \text { months; } n=44 \\
\text { Control arm: the same dosage of placebo; } n=45\end{array}$ & $\begin{array}{l}\text { LCSGJ stage I-III; mean tumour number } 1.5 \text { for } \\
\text { study arm and } 1.4 \text { for control arm; mean tumour } \\
\text { size } 2.9 \mathrm{~cm} \text { for study arm and } 3.0 \mathrm{~cm} \text { for control } \\
\text { arm }\end{array}$ & HCV $75 \%$ & $\begin{array}{l}\text { Median } 38 \text { or } \\
62 \text { months }\end{array}$ \\
\hline
\end{tabular}

Vitamin $\mathrm{K} 2$ analogue

Mizuta et al (52) Study arm: oral menatetrenone 45 mg/day until recurrence; $n=32$

Control arm: no adjuvant therapy; $n=29$
LCSGJ stage I-III; mean tumour number 1.5; mean tumour size $18 \mathrm{~mm}^{2}$ for study arm and $19 \mathrm{~mm}^{2}$ for control arm; vascular invasion $0 \%$

\section{C-P A 79\%; $\quad$ Median 28.9 \\ HCV $89 \%$ months for study arm and 27.7 months for control arm}

Single tumour 44\%; mean tumour size $\leq 3 \mathrm{~cm} 80 \%$ C-P A 60\%; HC Median 19.5 $\vee 73 \% \quad$ months for study arm and 16.5 months for control arm

LCSGJ stage I-III; single tumour 68\%; mean C-P A 73\%; NR tumour size $20 \mathrm{~mm}$ for study arm and $25 \mathrm{~mm}$ for HCV $100 \%$ control arm; vascular invasion 0\%

Single tumour 71\%; median tumour size $19 \mathrm{~mm}$; vascular invasion $0 \%$

C-P A $87 \%$; NR cirrhosis 78\%; HCV $83 \%$

Study arm 2: oral menatetrenone $90 \mathrm{mg} /$ day until recurrence; $n=185$

Control arm: the same dosage of placebo; $\mathrm{n}=181$

C-P Child Child-Pugh class; HCV Hepatitis C virus; LCSGJ Liver Cancer Study Group of Japan; NR Not reported

CI 0.42 to 0.71$])$. There was no heterogeneity among these studies $\left(\mathrm{I}^{2}=0 \%\right)$.

Other therapeutic modalities: Cancer vaccine therapy (59) and radioimmunotherapy (62) achieved significantly higher RFS (HR 0.19 [95\% CI 0.05 to 0.69]) and longer TTR (HR 0.28 [95\% CI 0.12 to
0.66]) compared with control, respectively; adjuvant therapy with ${ }^{131}$ I-lipiodol $(60,61)$ or PI-88 (63) tended to decrease the risk of recurrence, although difference in RFS (HR 0.58 [95\% CI 0.25 to 1.32]) or TTR (HR 0.63 [95\% CI 0.34 to 1.15]) between adjuvant and no adjuvant therapy groups failed to reach statistical significance. 
TABLE 8

Methodological quality assessment of the randomized controlled trials evaluating adjuvant vitamin analogue therapy

\begin{tabular}{|c|c|c|c|c|c|c|}
\hline \multirow[b]{2}{*}{ Study (reference) } & \multirow[b]{2}{*}{$\begin{array}{l}\text { Random sequence } \\
\text { generation }\end{array}$} & \multirow[b]{2}{*}{$\begin{array}{c}\text { Allocation } \\
\text { concealment }\end{array}$} & \multirow[b]{2}{*}{$\begin{array}{l}\text { Incomplete } \\
\text { outcome data }\end{array}$} & \multirow[b]{2}{*}{ Selective reporting } & \multicolumn{2}{|l|}{ Other bias } \\
\hline & & & & & $\begin{array}{c}\text { Balanced in baseline } \\
\text { characteristics }\end{array}$ & $\begin{array}{c}\text { Sample size } \\
\text { calculation }\end{array}$ \\
\hline Muto et al $(50,51)$ & $\begin{array}{l}\text { Unclear: unspecified } \\
\text { block } \\
\text { randomization }\end{array}$ & $\begin{array}{l}\text { Yes: by sequentially num- } \\
\text { bered drug containers } \\
\text { of identical appearance }\end{array}$ & Yes: analysis by ITT & $\begin{array}{l}\text { Unclear: the study protocol } \\
\text { was unavailable }\end{array}$ & Yes & Yes \\
\hline Mizuta et al (52) & $\begin{array}{l}\text { Yes: from a table of } \\
\text { random permuta- } \\
\text { tions }\end{array}$ & $\begin{array}{l}\text { Unclear: only stated as } \\
\text { random }\end{array}$ & Yes: analysis by ITT & $\begin{array}{l}\text { Unclear: the study protocol } \\
\text { was unavailable }\end{array}$ & $\begin{array}{l}\text { No: patients in the } \\
\text { treatment arm had } \\
\text { significantly lower serum } \\
\text { DCP level }\end{array}$ & No \\
\hline Hotta et al (53) & $\begin{array}{l}\text { Unclear: from an } \\
\text { unspecified } \\
\text { random list }\end{array}$ & $\begin{array}{l}\text { Unclear: only stated as } \\
\text { random }\end{array}$ & Yes: analysis by ITT & $\begin{array}{l}\text { Unclear: the study protocol } \\
\text { was unavailable }\end{array}$ & Yes & No \\
\hline Kakizaki et al (54) & $\begin{array}{l}\text { Unclear: only stated } \\
\text { as random }\end{array}$ & $\begin{array}{l}\text { Unclear: only stated as } \\
\text { random }\end{array}$ & $\begin{array}{l}\text { Unclear: ITT analysis } \\
\text { for patients treated } \\
\text { rather than random- } \\
\text { ized }\end{array}$ & $\begin{array}{l}\text { Unclear: the study protocol } \\
\text { was unavailable }\end{array}$ & Yes & No \\
\hline Yoshida et al (55) & $\begin{array}{l}\text { Yes: minimization } \\
\text { randomization }\end{array}$ & $\begin{array}{l}\text { Yes: by sequentially } \\
\text { numbered drug } \\
\text { containers of identical } \\
\text { appearance }\end{array}$ & $\begin{array}{l}\text { Yes: efficacy analysis } \\
\text { by ITT }\end{array}$ & $\begin{array}{l}\text { Yes: all expected outcomes } \\
\text { were reported in accor- } \\
\text { dance with the study pro- } \\
\text { tocol }\end{array}$ & $\begin{array}{l}\text { No: patients in the two } \\
\text { treatment arms had sig- } \\
\text { nificantly higher serum } \\
\text { TBIL and AST levels }\end{array}$ & Yes \\
\hline
\end{tabular}

AST Aspartate aminotransferase; DCP Des-gamma-carboxy prothrombin; ITT Intention-to-treat; TBIL Total bilirubin

TABLE 9

Characteristics of the randomized controlled trials evaluating adjuvant adoptive immunotherapy

\begin{tabular}{|c|c|c|c|c|}
\hline \multirow[b]{2}{*}{ Study (reference) } & \multirow[b]{2}{*}{ Adjuvant protocol and number of patients } & \multicolumn{2}{|c|}{ Patients' baseline characteristics } & \multirow[b]{2}{*}{ Follow-up } \\
\hline & & Tumor characteristics & Liver disease & \\
\hline Takayama et al (56) & $\begin{array}{l}\text { Study arm: iv LAK cell-based immunotherapy for } \\
5 \text { times (at weeks } 2,3,4,12 \text {, and } 24 \text { after curative } \\
\text { treatment); n=76 } \\
\text { Control arm: no adjuvant therapy; } n=74\end{array}$ & $\begin{array}{l}\text { Single tumour } 69 \% \text {; tumour size } \geq 3 \mathrm{~cm} 53 \% \text {; } \\
\text { intrahepatic metastasis or vascular invasion } \\
56 \%\end{array}$ & $\begin{array}{l}\text { C-P A } 69 \% ; \text { cirrho- } \\
\text { sis } 51 \% ; \mathrm{HCV} \\
66 \%\end{array}$ & $\begin{array}{l}\text { Median } \\
4.4 \text { years }\end{array}$ \\
\hline Weng et al (57) & $\begin{array}{l}\text { Study arm: Transhepatic arterial CIK cell-based immu- } \\
\text { notherapy for 8-10 times (2-week intervals); } n=45 \\
\text { Control arm: no adjuvant therapy; } n=40\end{array}$ & Tumour size $\geq 5 \mathrm{~cm} 56 \%$; vascular invasion $0 \%$ & C-P A $81 \%$ & 18 months \\
\hline Hui et al (58) & $\begin{array}{l}\text { Study arm 1: iv CIK cell-based immunotherapy for } \\
3 \text { times ( } 2 \text {-week intervals); } n=41 \\
\text { Study arm 2: iv CIK cell-based immunotherapy for } \\
6 \text { times (2-week intervals); } n=43 \\
\text { Control arm: no adjuvant therapy; } n=43\end{array}$ & $\begin{array}{l}\text { Single tumour } 100 \% \text {; tumour size } \geq 5 \mathrm{~cm} 55 \% \text {; } \\
\text { vascular invasion } 46 \%\end{array}$ & $\begin{array}{l}\text { C-P A } 80 \% \text {; } \\
\text { cirrhosis } 80 \% \text {; } \\
\text { HBV } 76 \%\end{array}$ & $5-7$ years \\
\hline
\end{tabular}

C-P Child Child-Pugh class; CIK Cytokine-induced killer; HBV Hepatitis B virus; HCV Hepatitis C virus; iv Intravenous; LAK Lymphokine activated killer;

TABLE 10

Methodological quality assessment of the randomized controlled trials evaluating adjuvant adoptive immunotherapy

\begin{tabular}{|c|c|c|c|c|c|c|}
\hline \multirow[b]{2}{*}{ Study (reference) } & \multirow[b]{2}{*}{$\begin{array}{c}\text { Random sequence } \\
\text { generation }\end{array}$} & \multirow[b]{2}{*}{$\begin{array}{c}\text { Allocation } \\
\text { concealment }\end{array}$} & \multirow[b]{2}{*}{$\begin{array}{l}\text { Incomplete } \\
\text { outcome data }\end{array}$} & \multirow[b]{2}{*}{ Selective reporting } & \multicolumn{2}{|c|}{ Other bias } \\
\hline & & & & & $\begin{array}{l}\text { Balanced in base- } \\
\text { line characteristics }\end{array}$ & $\begin{array}{c}\text { Sample size } \\
\text { calculation }\end{array}$ \\
\hline Takayama et al (56) & $\begin{array}{l}\text { Unclear: unspecified } \\
\text { block randomization }\end{array}$ & $\begin{array}{l}\text { Unclear: only stated } \\
\text { as random }\end{array}$ & Yes: analysis by ITT & $\begin{array}{l}\text { Unclear: the study protocol } \\
\text { was unavailable }\end{array}$ & Yes & Yes \\
\hline Weng et al (57) & $\begin{array}{l}\text { Unclear: only stated as } \\
\text { random }\end{array}$ & $\begin{array}{l}\text { Unclear: only stated } \\
\text { as random }\end{array}$ & Yes: analysis by ITT & $\begin{array}{l}\text { Unclear: result of TTR was } \\
\text { not presented }\end{array}$ & Yes & Yes \\
\hline Hui et al (58) & Yes: by drawing of lots & $\begin{array}{l}\text { Unclear: only stated } \\
\text { as random }\end{array}$ & Yes: analysis by ITT & $\begin{array}{l}\text { Unclear: the study protocol } \\
\text { was unavailable }\end{array}$ & Yes & No \\
\hline
\end{tabular}

ITT Intention-to-treat; TTR Time to recurrence

\section{OS}

Twenty-two trials $(33-36,38-40,44,45,47-50,52-56,58,59,61,62)$ provided OS data. Nevertheless, due to the insufficient data reporting for the calculation of HR, three $(47,53,55)$ of these 22 studies were further excluded from the analysis of the outcome. Seven subgroup analyses were performed for OS (Figure 4).

Chemotherapy: The meta-analysis for seven (33-36,38-40) trials assessing adjuvant chemotherapy yielded a nonsignificant but heterogeneous result (HR 1.01 [95\% CI 0.76 to 1.35$] ; \mathrm{I}^{2}=64 \%$ ). The separate subgroup analysis (Figure 5) in terms of different routes of administration demonstrated that adjuvant oral (HR 1.01 [95\% CI 0.70 to 1.47$] ; \mathrm{I}^{2}=75 \%$ ) or transhepatic arterial chemotherapy (HR 0.59 [95\% CI 0.31 to 1.14 ]; $\mathrm{I}^{2}=62 \%$ ) did not indentify an OS gain, while the combination of systemic and transhepatic arterial chemotherapy had a trend favouring no adjuvant therapy (HR 1.67 [95\% CI 0.88 to 3.16$\left.] ; \mathrm{I}^{2}=12 \%\right)$.

IFN therapy: The pooled HR of 0.52 (95\% CI 0.38 to 0.71 ) among four $(44,45,48,49)$ trials in favour of adjuvant group demonstrated a convincing benefit of IFN therapy over no adjuvant therapy in OS. There was no heterogeneity among trials $\left(\mathrm{I}^{2}=0 \%\right)$. 
TABLE 11

Characteristics of the randomized controlled trials evaluating other adjuvant therapies

\begin{tabular}{|c|c|c|c|c|}
\hline \multirow{2}{*}{$\begin{array}{l}\text { Study } \\
\text { (reference) }\end{array}$} & \multirow[b]{2}{*}{ Adjuvant protocol and number of patients } & \multicolumn{2}{|l|}{ Patients' baseline characteristics } & \multirow[b]{2}{*}{ Follow-up } \\
\hline & & Tumour characteristics & Liver disease & \\
\hline \multicolumn{5}{|c|}{ Cancer vaccine therapy } \\
\hline $\begin{array}{l}\text { Kuang et al } \\
\text { (59) }\end{array}$ & $\begin{array}{l}\text { Study arm: intradermal injection of autologous formalin-fixed } \\
\text { tumour vaccine for } 3 \text { courses (one course consisted of } \\
5 \text { injections of the tumour vaccine followed by a two-week } \\
\text { interval); } n=18 \\
\text { Control arm: no adjuvant therapy; } n=21\end{array}$ & $\begin{array}{l}\text { TNM stage I-IIIA; single tumour } 95 \% \text {; tumour size } \\
\geq 5 \mathrm{~cm} 51 \% \text {; intrahepatic metastasis or vascular } \\
\text { invasion } 33 \%\end{array}$ & $\begin{array}{l}\text { C-P A } 92 \% \text {; cir- } \\
\text { rhosis 54\%; } \\
\text { HBV } 90 \%\end{array}$ & $\begin{array}{c}\text { Median } 15 \\
\text { months }\end{array}$ \\
\hline \multicolumn{5}{|c|}{ Antibody targeted radioimmunotherapy } \\
\hline Xu et al (62) & $\begin{array}{l}\text { Study arm: iv } \mathrm{hLicartin^{ \star \dagger }} 15.4 \mathrm{MBq} / \mathrm{kg} \text { for } \\
3 \text { times (28-day intervals); } \mathrm{n}=30 \\
\text { Control arm: the same dosage of placebo; } \mathrm{n}=30\end{array}$ & $\begin{array}{l}\text { TNM stage III-IV; single lesion with tumour size } \\
>5 \mathrm{~cm} 72 \% \text {; multiple lesion with tumour size } \\
>3 \mathrm{~cm} \text { 28\%; portal vein cancer thrombi } 45 \%\end{array}$ & $\begin{array}{l}\text { C-P A } 43 \% \text {; cir- } \\
\text { rhosis 100\%; } \\
\text { HBV } 88 \%\end{array}$ & $\begin{array}{l}\text { Median } 12.3 \\
\text { months }\end{array}$ \\
\hline
\end{tabular}

*Iodine 131-labelled metuximab (HAb18 F[ab']2). ${ }^{\dagger}$ Chengdu Hoist Hitech Co Ltd, China; and the Fourth Military Medical University, Xi'an, China. C-P Child ChildPugh class; iv Intravenous.

TABLE 12

Methodological quality assessment of the randomized evaluating other adjuvant therapies

\begin{tabular}{|c|c|c|c|c|c|c|}
\hline \multirow[b]{2}{*}{ Study (reference) } & \multirow[b]{2}{*}{$\begin{array}{c}\text { Random sequence } \\
\text { generation }\end{array}$} & \multirow[b]{2}{*}{$\begin{array}{c}\text { Allocation } \\
\text { concealment }\end{array}$} & \multirow[b]{2}{*}{ Incomplete outcome data } & \multirow[b]{2}{*}{ Selective reporting } & \multicolumn{2}{|c|}{ Other bias } \\
\hline & & & & & $\begin{array}{c}\text { Balanced in baseline } \\
\text { characteristics }\end{array}$ & $\begin{array}{c}\text { Sample size } \\
\text { calculation }\end{array}$ \\
\hline Kuang et al (59) & $\begin{array}{l}\text { Unclear: unspecified } \\
\text { block randomization }\end{array}$ & $\begin{array}{l}\text { Unclear: by an } \\
\text { independent } \\
\text { investigator }\end{array}$ & $\begin{array}{l}\text { Unclear: ITT analysis } \\
\text { excluded } 2 \text { randomized } \\
\text { patients. }\end{array}$ & $\begin{array}{l}\text { Unclear: the study } \\
\text { protocol was } \\
\text { unavailable }\end{array}$ & Yes & Yes \\
\hline Lau et al $(60,61)$ & $\begin{array}{l}\text { Yes: computer- } \\
\text { generated random } \\
\text { number }\end{array}$ & $\begin{array}{l}\text { Unclear: only stated as } \\
\text { random }\end{array}$ & Yes: analysis by ITT & $\begin{array}{l}\text { Unclear: the study } \\
\text { protocol was } \\
\text { unavailable }\end{array}$ & Yes & Yes \\
\hline Xu et al (62) & $\begin{array}{l}\text { Unclear: randomization } \\
\text { by doctors }\end{array}$ & $\begin{array}{l}\text { Yes: by sequentially } \\
\text { numbered drug } \\
\text { containers of } \\
\text { identical appearance }\end{array}$ & Yes: analysis by ITT & $\begin{array}{l}\text { Unclear: the study } \\
\text { protocol was } \\
\text { unavailable }\end{array}$ & Yes & Yes \\
\hline Liu et al (63) & $\begin{array}{l}\text { Unclear: unspecified } \\
\text { block randomization }\end{array}$ & $\begin{array}{l}\text { Yes: pharmacy- } \\
\text { controlled } \\
\text { randomization }\end{array}$ & $\begin{array}{l}\text { Unclear: ITT analysis } \\
\text { excluded } 1 \text { patient ran- } \\
\text { domized to the treatment } \\
\text { group }\end{array}$ & $\begin{array}{l}\text { Unclear: the study } \\
\text { protocol was } \\
\text { unavailable }\end{array}$ & Yes & Yes \\
\hline
\end{tabular}

ITT Intention-to-treat

Vitamin analogue therapy: The meta-analysis for three trials $(51,52,54)$ showed that adjuvant therapy with VK2 analogue significantly improved OS compared with control, with no heterogeneity across the trials (HR 0.48 [95\% CI 0.29 to 0.82$] ; \mathrm{I}^{2}=0 \%$ ).

Adoptive immunotherapy: The pooled HRs for two trials $(56,58)$ testing adoptive immunotherapy demonstrated there was no significant difference between adjuvant and no adjuvant groups in terms of OS (HR 0.79 [95\% CI 0.55 to 1.14$]$ ). An acceptable heterogeneity was observed between the trials $\left(I^{2}=25 \%\right)$.

Other therapeutic modalities: The HR of OS for the trial of cancer vaccine therapy (59) was 0.07 (95\% CI 0.02 to 0.27 ), and that for the radioimmunotherapy study (62) was 0.26 (95\% CI 0.08 to 0.83$)$, each of which significantly favoured adjuvant therapy. However, OS in the internal radiation trial $(60,61)$ did not differ significantly between adjuvant and the control groups (HR 0.68 [95\% CI 0.30 to 1.55]).
Side effects

All except one trial (37) reported data on side effects. In the studies of chemotherapy (33-36,38-40) and of IFN therapy (41-49), 24\% (50 of 212 ) and $11 \%$ (35 of 328) patients in adjuvant group, respectively, developed severe toxicity or treatment-related side effects requiring a discontinuation of adjuvant therapy, while cancer vaccine (59), adoptive immunotherapy (56-58) and heparanase inhibitor PI-88 therapy (63) caused frequent but mild adverse effects. Other adjuvant modalities such as vitamin analogue therapy (50-55), internal radiation therapy $(60,61)$ and radioimmunotherapy $(62)$ appeared to be safe, because side effects of these therapies were barely reported in the publications.

\section{DISCUSSION}

$\mathrm{HCC}$ is a major health problem in hepatitis-prevalent countries such as China (1-3). Despite great improvement in diagnostic and 


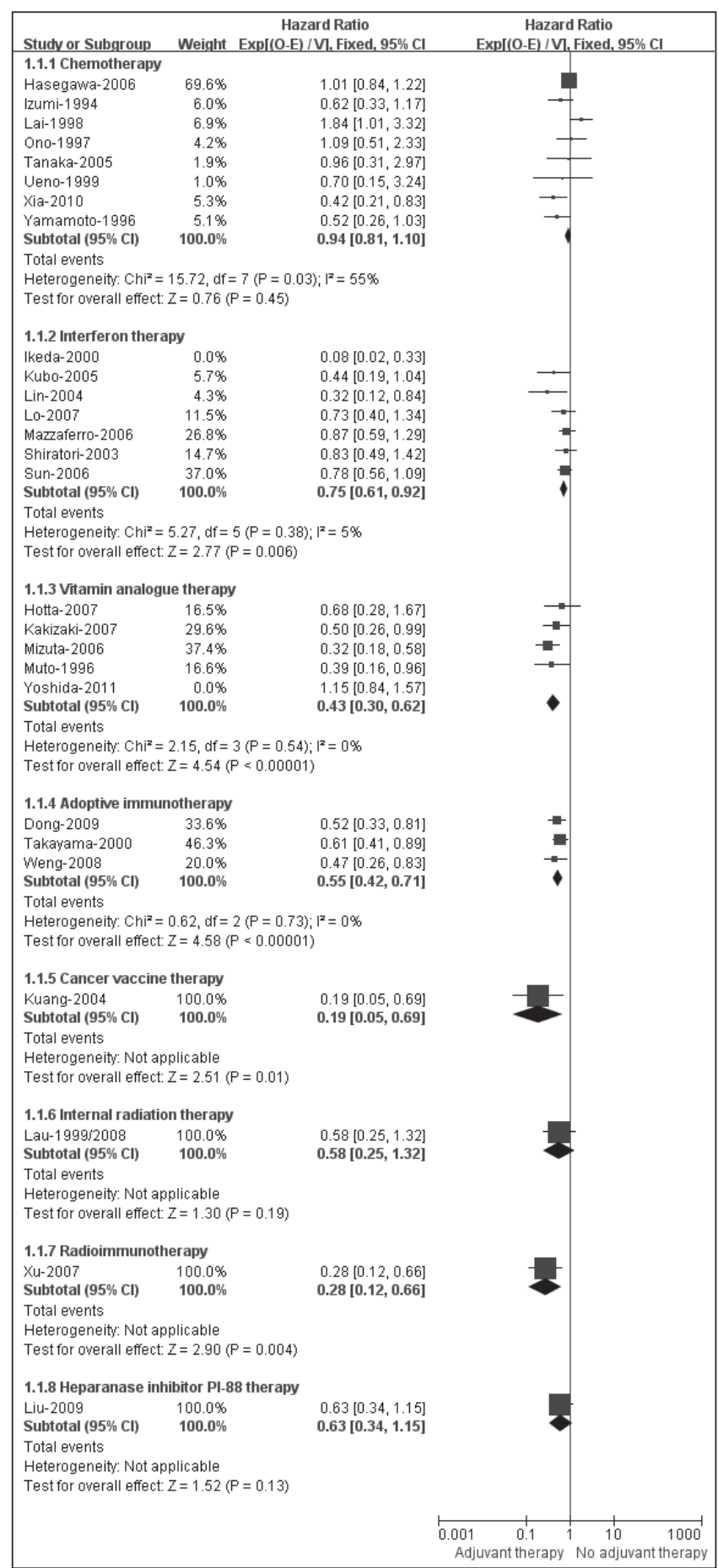

Figure 2) Meta-analysis (sensitivity analysis) of recurrence-free survival in randomized controlled trials evaluating adjuvant therapy

therapeutic techniques, the long-term outcomes of HCC remain unsatisfactory, even after treatment with cure intent. From our analysis for patients receiving no active adjuvant therapy, the median five-year recurrence rate after surgical resection, liver transplantation or ablation therapy was up to $82 \%$ (range $55 \%$ to $94 \%$ ), and that for survival rate at five years was $48 \%$ (range $29 \%$ to $75 \%$ ). The high recurrence rate was explained by intrahepatic metastasis of primary HCC, which accounted for $>79 \%$ of recurrence cases; the main cause of death after these potentially curative treatments was recurrent HCC $(67 \%$ to $100 \%$ ) that occurred mostly in residual liver.

The current meta-analysis included a broad spectrum of adjuvant therapies with either antitumour or chemopreventive effects to be

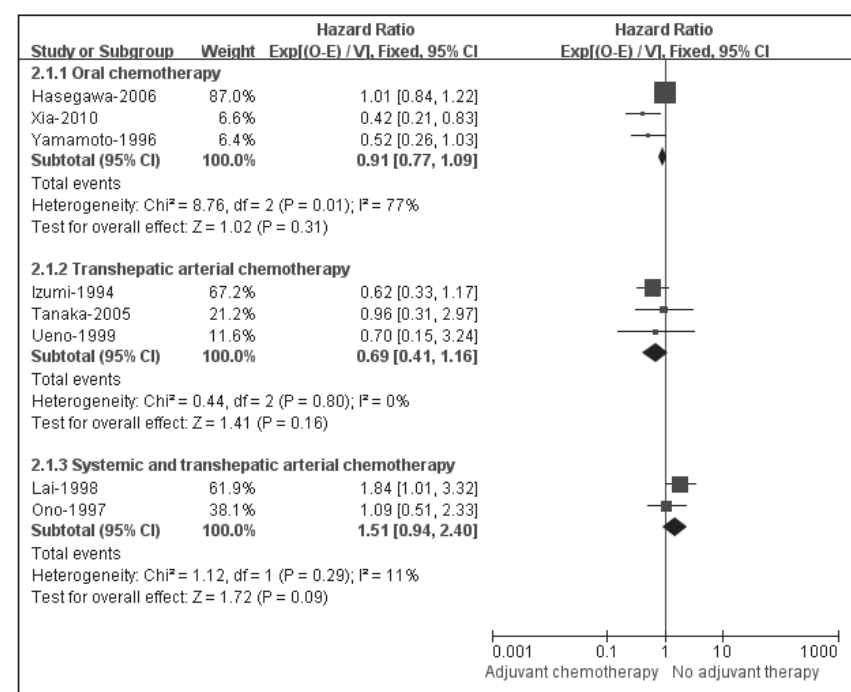

Figure 3) Subgroup analysis of recurrence-free survival in randomized controlled trials evaluating adjuvant chemotherapy

evaluated. Adjuvant chemotherapy failed to confer any benefit to RFS and OS, regardless of what agents or administration modes were used. On the contrary, the combination of systemic and transarterial chemotherapy may have a deleterious effect on patient prognosis. Although the efficacy results of the adjuvant IFN studies were encouraging, one caveat is that the survival benefits from IFN therapy should be weighed against the risks of adverse effects. The findings of chemoprevention with vitamin analogues require further examination because the meta-analysis of RFS and of OS was performed only in a limited number of small RCTs with methodological weaknesses. Adoptive immunotherapy with either LAK or CIK cells may be as promising a strategy as adjuvant therapy for HCC because it increased the RFS by $45 \%$ and resulted in few adverse effects, although the approaches are too cumbersome and costly for use in large clinical trials. Nevertheless, follow-up periods in these trials (56-58) were too short to confer a statistically significant benefit in OS. Postoperative adjuvant therapy using either transhepatic arterial ${ }^{131}$ I-lipiodol infusion or subcutaneous injection of heparanase inhibitor PI-88 did not appear able to decrease recurrence and to improve survival, while cancer vaccine therapy and Licartin radioimmunotherapy showed some promise after radical surgery for HCC. However, each of these modalities was examined in single trial with small-scale and preliminary settings.

The results of the current meta-analysis suggest that the effectiveness of an adjuvant modality depends largely on front-line therapy for HCC. In fact, because the cancer is insensitive to chemotherapy and radiotherapy (66), adjuvant use of any chemotherapeutic agent or radioactive material may not be effective. Furthermore, the beneficial effects of adjuvant IFN therapy on recurrence and survival may contribute to its efficacy in preventing hepatitis from developing into HCC $(67,68)$. On the other hand, the lack of effective therapeutic agents remains the main challenge in the provision of adjuvant therapy for HCC (9) because the presence of underlying cirrhosis limits the capability of remnant liver insulted by initially curative treatment to tolerate any adjuvant cytotoxic therapy. Nevertheless, because intrahepatic recurrence can either represent metastasis from primary HCC or de novo tumour formation in a cirrhotic liver, an agent or regimen with both tumouricidal and chemopreventive effects, but less toxicity, may be effective to prevent recurrence after curative treatment for $\operatorname{HCC}(7,61,69)$. In the current analysis, however, the effect of adjuvant therapy on metachronous de novo carcinogenesis may have been obscured because of the presence of recurrence resulting from intrahepatic metastases of HCC, and because most of the trials lacked a precise description of the difference between primary metastasis and de novo HCC. For future trials, therefore, measures for 


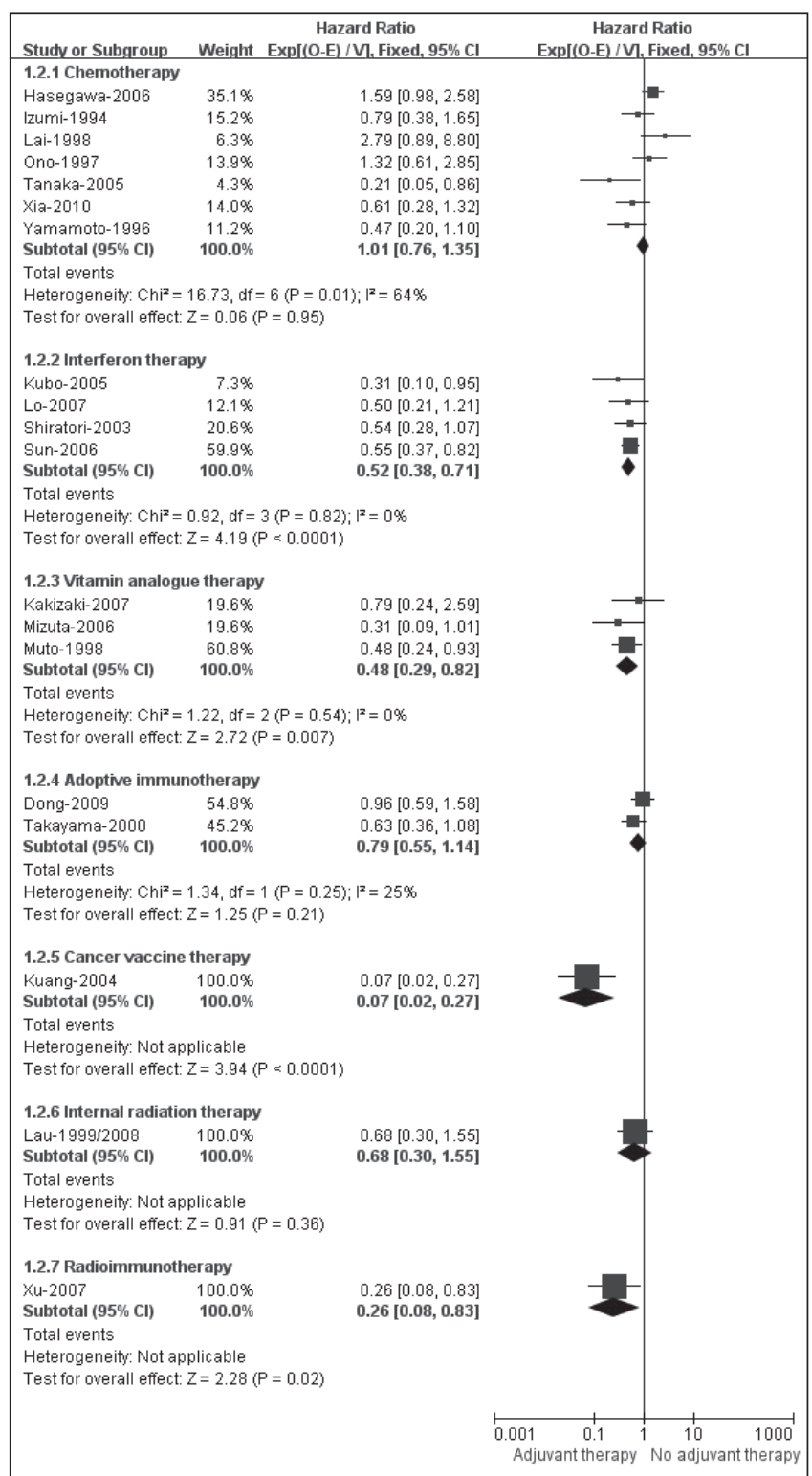

Figure 4) Meta-analysis of overall survival in randomized controlled trials evaluating adjuvant therapy

metastatic recurrence in the residual liver may be necessary, and molecular diagnostic techniques, such as comparative genomic hybridization, integration pattern of HBV, or DNA fingerprinting using loss of heterozygosity assays or microarray analysis (70-72) are recommended, if feasible, to differentiate the two types of recurrence.

Theoretically, reduced recurrence is expected to improve survival. Nevertheless, several trials $(38,44,48)$ found an improvement in OS but not in RFS. These were studies that had relatively small number of participants and insufficient follow-up, and there was little consideration of statistical power in the design. These limitations, however, may prevent or delay recognition of potentially beneficial therapies. Furthermore, effects of adjuvant therapy may differ over time. This was apparent in studies involving polyprenoic acid $(50,51)$ and internal radiation therapy $(60,61)$, in which the benefits in decreasing recurrence became more evident or were lost after expending follow-up visits. Therefore, larger sample sizes and longer periods of observation are emphasized for future trials.

For trials testing adjuvant therapy, any adjuvant effect should be evaluated independently from other potential effects. The database searches initially identified 19 reports on adjuvant therapies in which

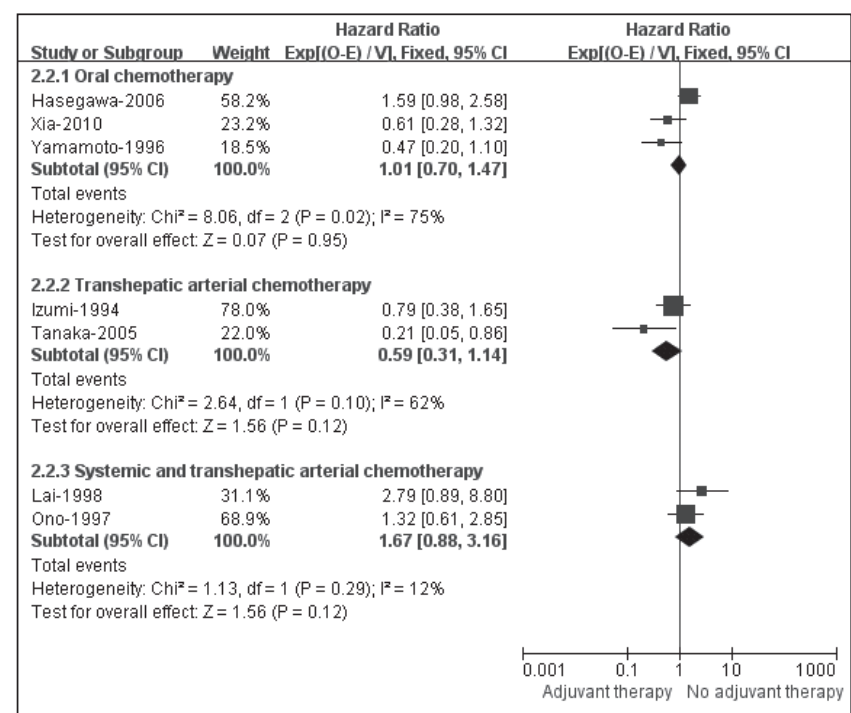

Figure 5) Subgroup analysis of overall survival in randomized controlled trials evaluating adjuvant chemotherapy

randomization was performed before patients underwent mainly curative resection for HCC (Figure 1). Although postoperative recurrence was addressed, these studies were not considered for inclusion because adjuvant effects in treatment group may have been confounded by the introduction of initially curative treatment. Also, it is crucial to distinguish recurrent disease after a curative treatment from residual tumour after a palliative therapy when testing an adjuvant therapy that aims primarily to decrease the recurrence of HCC. Therefore, proper documentation of curability of initial treatment for HCC is necessary. The curability in most of the trials included was defined as the complete elimination or necrosis of all macroscopically detectable tumours, with no demonstrable evidence of residual or recurrent tumours on image studies before initiation of adjuvant therapy. However, it was either not described at all, or insufficiently described by other trials $(34,38,41,55,62)$, which may have resulted in inadvertent enrollment of patients with residual HCC before randomization. Nevertheless, given that there have been no established assessment criteria of curability after surgical resection or ablation therapy, a more stringent definition of curability is required.

One of the major weakness of the present meta-analysis is that the generalizability of the results was limited by predominantly including RCTs conducted among Japanese and Chinese patients. Conceivably, there could be differences in the natural history of HCC among geographical regions, although these potential differences have not been well understood. Therefore, it is possible that the findings of the current meta-analysis may not be extrapolated to the non-Asian population.

Another limitation is that the study failed to detect the impact of underlying liver disease, particularly cirrhosis, on survival outcomes. A meta-regression analysis could be helpful to capture the effect of liver cirrhosis on survival. Nevertheless, it is hardly believable that a metaregression analysis using cirrhosis as a covariate could affect the overall results of the current study because the majority of deaths were due to HCC recurrence rather than to liver cirrhosis (Figure 2). On the other hand, the use of RFS as primary outcome could potentially confound effects of adjuvant therapies on survival by involving death from liver failure. In the current meta-analysis, we initially planned to include TTR as the primary outcome. However, because only a few studies reported TTR $(35,56,57,59)$ or presented data for estimating the HR of the outcome $(41,45,46,52-54,62)$, RFS was used as a surrogate. Furthermore, we found the difference in the estimates of the HR between TTR and RFS in the trials $(35,56,57,59)$ that reported either of the outcomes was minor (data not shown). Again, RFS or DFS may be preferable to TTR as a correlate of OS, because it is able to capture 
fatal toxicity in trials where the majority of deaths are expected to be related to cancer (73). Nevertheless, given the confounding composite nature of RFS that concerns not only recurrence but also death from any cause, death resulting from the natural history of cirrhosis may confound detection of potential benefits from adjuvant therapy $(8,74)$. Therefore, the overall results of RFS in the meta-analysis should be interpreted with care, and TTR is recommended for further adjuvant trials in HCC.

Third, the present study has the typical weakness of an aggregated data meta-analysis of time-to-event outcomes. Of the 31 study reports included, only four $(34,35,55,59)$ directly presented HR and associated $95 \%$ CIs for RFS or OS, while results of these outcomes for most of the trials were obtained by performing calculations using other statistics or data extracted from published survival curves $(25,26)$. Bias may have been produced in estimating the HR with the use of these indirect methods, which may, however, partially explain the statistical heterogeneity among individual comparisons. Nevertheless, in the absence of necessary statistics, a meta-analysis based on data from published curves can be the only practical alternative (25). Future publications reporting time-to-event outcomes should, therefore, provide more detailed statistical information, preferably in the form of the results of $\log$ HRs and their variances, or their estimators (75).

The current meta-analysis assessed methodological quality of the included RCTs using rigorous criteria proposed by the Cochrane

\section{REFERENCES}

1. Ferlay J, Shin HR, Bray F, et al. Estimates of worldwide burden of cancer in 2008: GLOBOCAN 2008. Int J Cancer 2010;127:2893-917.

2. Liu J, Fan D. Hepatitis B in China. Lancet 2007;369:1582-3.

3. Tang ZY, Ye SL, Liu YK, et al. A decade's studies on metastasis of hepatocellular carcinoma. J Cancer Res Clin Oncol 2004;130:187-96.

4. Zhou Y, Zhao Y, Li B, et al. Meta-analysis of radiofrequency ablation versus hepatic resection for small hepatocellular carcinoma. BMC Gastroenterol 2010;10:78.

5. Chen MS, Li JQ, Zheng Y, et al. A prospective randomized trial comparing percutaneous local ablative therapy and partial hepatectomy for small hepatocellular carcinoma. Ann Surg 2006;243:321-8.

6. Ercolani G, Grazi GL, Ravaioli M, et al. Liver resection for hepatocellular carcinoma on cirrhosis: Univariate and multivariate analysis of risk factors for intrahepatic recurrence. Ann Surg 2003;237:536-43.

7. Poon RT, Fan ST, Lo CM, et al. Long-term survival and pattern of recurrence after resection of small hepatocellular carcinoma in patients with preserved liver function: Implications for a strategy of salvage transplantation. Ann Surg 2002;235:373-82.

8. Llovet JM, Bruix J. Novel advancements in the management of hepatocellular carcinoma in 2008. J Hepatol 2008;48 Suppl 1:S20-37.

9. Thomas MB, Jaffe D, Choti MM, et al. Hepatocellular carcinoma: Consensus recommendations of the National Cancer Institute Clinical Trials Planning Meeting. J Clin Oncol 2010;28:3994-4005.

10. Schwartz JD, Schwartz M, Mandeli J, et al. Neoadjuvant and adjuvant therapy for resectable hepatocellular carcinoma: Review of the randomised clinical trials. Lancet Oncol 2002;3:593-603.

11. Sun HC, Tang ZY. Preventive treatments for recurrence after curative resection of hepatocellular carcinoma - a literature review of randomized control trials. World J Gastroenterol 2003;9:635-40.

12. Mathurin P, Raynard B, Dharancy S, et al. Meta-analysis: Evaluation of adjuvant therapy after curative liver resection for hepatocellular carcinoma. Aliment Pharmacol Ther 2003;17:1247-61.

13. Lau WY, Lai EC, Lau SH. The current role of neoadjuvant/ adjuvant/chemoprevention therapy in partial hepatectomy for hepatocellular carcinoma: A systematic review. Hepatobiliary Pancreat Dis Int 2009;8:124-33.

14. Samuel M, Chow PK, Chan Shih-Yen E, et al. Neoadjuvant and adjuvant therapy for surgical resection of hepatocellular carcinoma. Cochrane Database Syst Rev 2009;CD001199.

15. Ono T, Yamanoi A, Nazmy El Assal O, et al. Adjuvant chemotherapy after resection of hepatocellular carcinoma causes deterioration of long-term prognosis in cirrhotic patients: Metaanalysis of three randomized controlled trials. Cancer 2001;91:2378-85. systematic review (31). As a result, only nine RCTs included were assessed as having adequate quality $(34,44,47-50,55,61,62)$, while nearly one-half of the trials were subject to methodological weakness. Hence, the overall results of the present meta-analysis were prone to bias that was incurred from the bias of these original studies. Therefore, more prospective studies of good methodological quality are needed for adjuvant HCC clinical trials.

\section{CONCLUSIONS}

The prognosis of patients with HCC after potentially curative treatment is poor. Adjuvant IFN therapy can improve both RFS and OS, but the benefits of using this agent should be weighed against side effects. Combination of systemic and transhepatic arterial chemotherapy is not currently recommended for patients with HCC after potentially curative treatment. Other adjuvant therapies produce limited success for survival. Further well-designed RCTs with sufficient sample size and follow-up are required to establish the role of adjuvant therapies for HCC, and new agents or regimens with both antitumor and chemopreventive effects are expected.

DISCLOSURES: The authors have no financial disclosures or conflicts of interest ot declare.

16. Zhong JH, Li LQ. Postoperative adjuvant transarterial chemoembolization for participants with hepatocellular carcinoma: A meta-analysis. Hepatol Res 2010;40:943-53.

17. Breitenstein S, Dimitroulis D, Petrowsky H, et al. Systematic review and meta-analysis of interferon after curative treatment of hepatocellular carcinoma in patients with viral hepatitis. Br J Surg 2009;96:975-81.

18. Zhang $\mathrm{CH}, \mathrm{Xu}$ GL, Jia WD, et al. Effects of interferon alpha treatment on recurrence and survival after complete resection or ablation of hepatocellular carcinoma: A meta-analysis of randomized controlled trials. Int J Cancer 2009;124:2982-8.

19. Miao RY, Zhao HT, Yang HY, et al. Postoperative adjuvant antiviral therapy for hepatitis B/C virus-related hepatocellular carcinoma: A meta-analysis. World J Gastroenterol 2010;16:2931-42.

20. Miyake Y, Takaki A, Iwasaki Y, et al. Meta-analysis: Interferon-alpha prevents the recurrence after curative treatment of hepatitis $C$ virusrelated hepatocellular carcinoma. J Viral Hepat 2010;17:287-92.

21. Shen YC, Hsu C, Chen LT, et al. Adjuvant interferon therapy after curative therapy for hepatocellular carcinoma (HCC): A meta-regression approach. J Hepatol 2010;52:889-94.

22. Singal AK, Freeman DH, Jr., Anand BS. Meta-analysis: interferon improves outcomes following ablation or resection of hepatocellular carcinoma. Aliment Pharmacol Ther 2010;32:851-8.

23. Wong JS, Wong GL, Tsoi KK, et al. Meta-analysis: The efficacy of anti-viral therapy in prevention of recurrence after curative treatment of chronic hepatitis B-related hepatocellular carcinoma. Aliment Pharmacol Ther 2011;33:1104-12.

24. Chu KJ, Lai EC, Yao XP, et al. Vitamin analogues in chemoprevention of hepatocellular carcinoma after resection or ablation - a systematic review and meta-analysis. Asian J Surg 2010;33:120-6.

25. Parmar MK, Torri V, Stewart L. Extracting summary statistics to perform meta-analyses of the published literature for survival endpoints. Stat Med 1998;17:2815-34.

26. Tierney JF, Stewart LA, Ghersi D, et al. Practical methods for incorporating summary time-to-event data into meta-analysis. Trials 2007;8:16.

27. Williamson PR, Smith CT, Hutton JL, et al. Aggregate data metaanalysis with time-to-event outcomes. Stat Med 2002;21:3337-51.

28. Poon RT, Fan ST, Ng IO, et al. Different risk factors and prognosis for early and late intrahepatic recurrence after resection of hepatocellular carcinoma. Cancer 2000;89:500-7.

29. Poon RT, Fan ST, Lo CM, et al. Long-term prognosis after resection of hepatocellular carcinoma associated with hepatitis B-related cirrhosis. J Clin Oncol 2000;18:1094-101.

30. Shimada M, Yamashita Y, Hamatsu T, et al. Surgical indications for advanced hepatocellular carcinoma. Hepatogastroenterology 2000;47:1095-9. 
31. Higgins JPT, Green S, eds. Cochrane Handbook for Systematic Reviews of Interventions Version 5.1.0. The Cochrane Collaboration, 2011. <www.cochrane-handbook.org > (Accessed January 2012).

32. Higgins JP, Thompson SG, Deeks JJ, et al. Measuring inconsistency in meta-analyses. BMJ 2003;327:557-60.

33. Yamamoto M, Arii S, Sugahara K, et al. Adjuvant oral chemotherapy to prevent recurrence after curative resection for hepatocellular carcinoma. Br J Surg 1996;83:336-40.

34. Hasegawa K, Takayama T, Ijichi M, et al. Uracil-tegafur as an adjuvant for hepatocellular carcinoma: A randomized trial. Hepatology 2006;44:891-5.

35. Xia Y, Qiu Y, Li J, et al. Adjuvant therapy with capecitabine postpones recurrence of hepatocellular carcinoma after curative resection: A randomized controlled trial. Ann Surg Oncol 2010;17:3137-44

36. Izumi R, Shimizu K, Iyobe T, et al. Postoperative adjuvant hepatic arterial infusion of Lipiodol containing anticancer drugs in patients with hepatocellular carcinoma. Hepatology 1994;20:295-301.

37. Ueno S, Tanabe G, Yoshida A, et al. Postoperative prediction of and strategy for metastatic recurrent hepatocellular carcinoma according to histologic activity of hepatitis. Cancer 1999;86:248-54.

38. Tanaka S, Shimada M, Shirabe K, et al. A novel intrahepatic arterial chemotherapy after radical resection for advanced hepatocellular carcinoma. Hepatogastroenterology 2005;52:862-5.

39. Lai EC, Lo CM, Fan ST, et al. Postoperative adjuvant chemotherapy after curative resection of hepatocellular carcinoma: A randomized controlled trial. Arch Surg 1998;133:183-8.

40. Ono T, Nagasue N, Kohno H, et al. Adjuvant chemotherapy with epirubicin and carmofur after radical resection of hepatocellular carcinoma: A prospective randomized study. Semin Oncol 1997;24:S6-18-S6-25.

41. Ikeda K, Arase Y, Saitoh S, et al. Interferon beta prevents recurrence of hepatocellular carcinoma after complete resection or ablation of the primary tumor-A prospective randomized study of hepatitis C virus-related liver cancer. Hepatology 2000;32:228-32.

42. Kubo S, Nishiguchi S, Hirohashi K, et al. Effects of long-term postoperative interferon-alpha therapy on intrahepatic recurrence after resection of hepatitis $\mathrm{C}$ virus-related hepatocellular carcinoma. A randomized, controlled trial. Ann Intern Med 2001;134:963-7.

43. Kubo S, Nishiguchi S, Hirohashi K, et al. Randomized clinical trial of long-term outcome after resection of hepatitis $\mathrm{C}$ virus-related hepatocellular carcinoma by postoperative interferon therapy. Br J Surg 2002;89:418-22.

44. Nishiguchi S, Tamori A, Kubo S. Effect of long-term postoperative interferon therapy on intrahepatic recurrence and survival rate after resection of hepatitis $\mathrm{C}$ virus-related hepatocellular carcinoma. Intervirology 2005;48:71-5.

45. Shiratori Y, Shiina S, Teratani T, et al. Interferon therapy after tumor ablation improves prognosis in patients with hepatocellular carcinoma associated with hepatitis $\mathrm{C}$ virus. Ann Intern Med 2003;138:299-306.

46. Lin SM, Lin CJ, Hsu CW, et al. Prospective randomized controlled study of interferon-alpha in preventing hepatocellular carcinoma recurrence after medical ablation therapy for primary tumors. Cancer 2004;100:376-82.

47. Mazzaferro V, Romito R, Schiavo M, et al. Prevention of hepatocellular carcinoma recurrence with alpha-interferon after liver resection in HCV cirrhosis. Hepatology 2006;44:1543-54.

48. Sun HC, Tang ZY, Wang L, et al. Postoperative interferon alpha treatment postponed recurrence and improved overall survival in patients after curative resection of HBV-related hepatocellular carcinoma: A randomized clinical trial. J Cancer Res Clin Oncol 2006;132:458-65.

49. Lo CM, Liu CL, Chan SC, et al. A randomized, controlled trial of postoperative adjuvant interferon therapy after resection of hepatocellular carcinoma. Ann Surg 2007;245:831-42.

50. Muto Y, Moriwaki H, Ninomiya M, et al. Prevention of second primary tumors by an acyclic retinoid, polyprenoic acid, in patients with hepatocellular carcinoma. Hepatoma Prevention Study Group. N Engl J Med 1996;334:1561-7.

51. Muto Y, Moriwaki H, Saito A. Prevention of second primary tumors by an acyclic retinoid in patients with hepatocellular carcinoma. N Engl J Med 1999;340:1046-7.

52. Mizuta T, Ozaki I, Eguchi Y, et al. The effect of menatetrenone, a vitamin $\mathrm{K} 2$ analog, on disease recurrence and survival in patients with hepatocellular carcinoma after curative treatment: A pilot study. Cancer 2006;106:867-72.
53. Hotta N, Ayada M, Sato K, et al. Effect of vitamin K2 on the recurrence in patients with hepatocellular carcinoma. Hepatogastroenterology 2007;54:2073-7.

54. Kakizaki S, Sohara N, Sato K, et al. Preventive effects of vitamin K on recurrent disease in patients with hepatocellular carcinoma arising from hepatitis $\mathrm{C}$ viral infection. J Gastroenterol Hepatol 2007;22:518-22.

55. Yoshida H, Shiratori Y, Kudo M, et al. Effect of vitamin K2 on the recurrence of hepatocellular carcinoma. Hepatology 2011;54:532-40.

56. Takayama T, Sekine T, Makuuchi M, et al. Adoptive immunotherapy to lower postsurgical recurrence rates of hepatocellular carcinoma: A randomised trial. Lancet 2000;356:802-7.

57. Weng DS, Zhou J, Zhou QM, et al. Minimally invasive treatment combined with cytokine-induced killer cells therapy lower the short-term recurrence rates of hepatocellular carcinomas. J Immunother 2008;31:63-71.

58. Hui D, Qiang L, Jian W, et al. A randomized, controlled trial of postoperative adjuvant cytokine-induced killer cells immunotherapy after radical resection of hepatocellular carcinoma. Dig Liver Dis 2009;41:36-41.

59. Kuang M, Peng BG, Lu MD, et al. Phase II randomized trial of autologous formalin-fixed tumor vaccine for postsurgical recurrence of hepatocellular carcinoma. Clin Cancer Res 2004;10:1574-9.

60. Lau WY, Leung TW, Ho SK, et al. Adjuvant intra-arterial iodine131-labelled lipiodol for resectable hepatocellular carcinoma: A prospective randomised trial. Lancet 1999;353:797-801.

61. Lau WY, Lai EC, Leung TW, et al. Adjuvant intra-arterial iodine131-labeled lipiodol for resectable hepatocellular carcinoma: A prospective randomized trial-update on 5-year and 10-year survival. Ann Surg 2008;247:43-8.

62. Xu J, Shen ZY, Chen XG, et al. A randomized controlled trial of Licartin for preventing hepatoma recurrence after liver transplantation. Hepatology 2007;45:269-76.

63. Liu CJ, Lee PH, Lin DY, et al. Heparanase inhibitor PI-88 as adjuvant therapy for hepatocellular carcinoma after curative resection: A randomized phase II trial for safety and optimal dosage. J Hepatol 2009;50:958-68.

64. Pan CC, Huang ZL, Li W, et al. Serum alpha-fetoprotein measurement in predicting clinical outcome related to autologous cytokine-induced killer cells in patients with hepatocellular carcinoma undergone minimally invasive therapy. Chin J Cancer 2010;29:596-602.

65. Moher D, Liberati A, Tetzlaff J, et al. Preferred reporting items for systematic reviews and meta-analyses: The PRISMA statement. BMJ 2009;339:b2535.

66. Avila MA, Berasain C, Sangro B, et al. New therapies for hepatocellular carcinoma. Oncogene 2006;25:3866-84.

67. Nishiguchi S, Kuroki T, Nakatani S, et al. Randomised trial of effects of interferon-alpha on incidence of hepatocellular carcinoma in chronic active hepatitis $\mathrm{C}$ with cirrhosis. Lancet 1995;346:1051-5.

68. Ikeda K, Saitoh S, Suzuki Y, et al. Interferon decreases hepatocellular carcinogenesis in patients with cirrhosis caused by the hepatitis B virus: A pilot study. Cancer 1998;82:827-35.

69. Kumada T, Nakano S, Takeda I, et al. Patterns of recurrence after initial treatment in patients with small hepatocellular carcinoma. Hepatology 1997;25:87-92.

70. Chen YJ, Yeh SH, Chen JT, et al. Chromosomal changes and clonality relationship between primary and recurrent hepatocellular carcinoma. Gastroenterology 2000;119:431-40.

71. Ng IO, Guan XY, Poon RT, et al. Determination of the molecular relationship between multiple tumour nodules in hepatocellular carcinoma differentiates multicentric origin from intrahepatic metastasis. J Pathol 2003;199:345-53.

72. Cheung ST, Chen X, Guan XY, et al. Identify metastasis-associated genes in hepatocellular carcinoma through clonality delineation for multinodular tumor. Cancer Res 2002;62:4711-21.

73. Sargent D. General and statistical hierarchy of appropriate biologic endpoints. Oncology (Williston Park) 2006;20:5-9.

74. Llovet JM, Di Bisceglie AM, Bruix J, et al. Design and endpoints of clinical trials in hepatocellular carcinoma. J Natl Cancer Inst 2008;100:698-711.

75. Michiels S, Piedbois P, Burdett S, et al. Meta-analysis when only the median survival times are known: A comparison with individual patient data results. Int J Technol Assess Health Care 2005;21:119-25. 


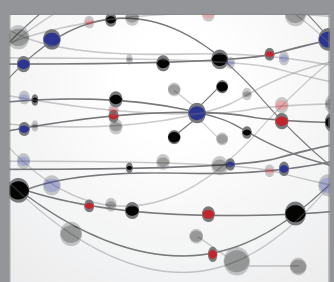

The Scientific World Journal
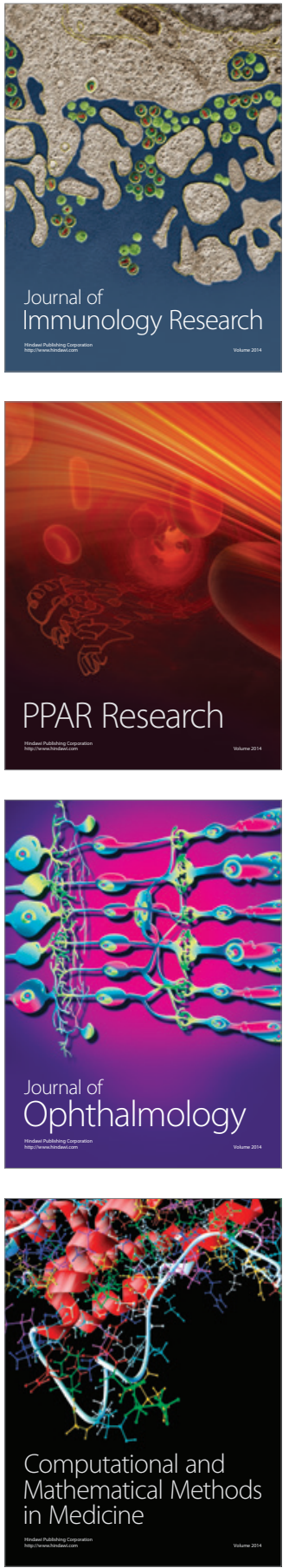

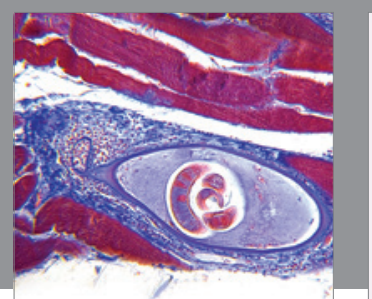

Gastroenterology Research and Practice

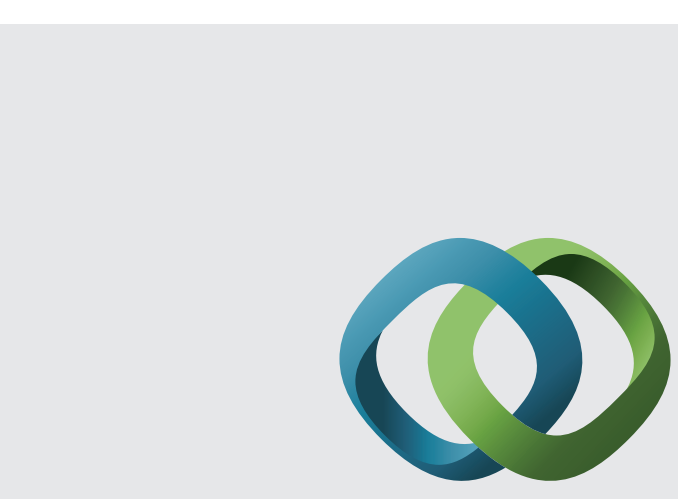

\section{Hindawi}

Submit your manuscripts at

http://www.hindawi.com
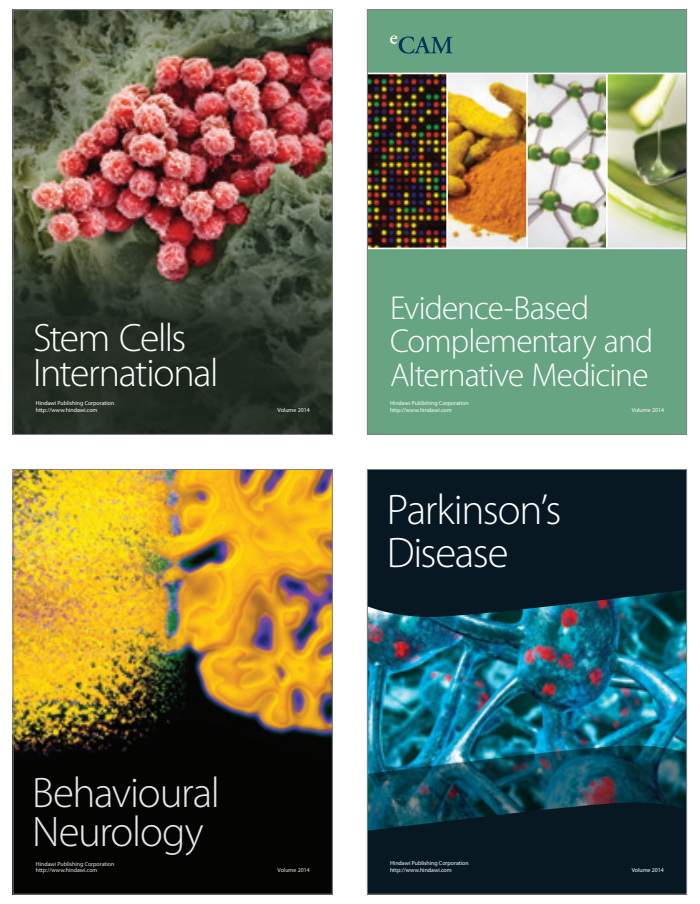
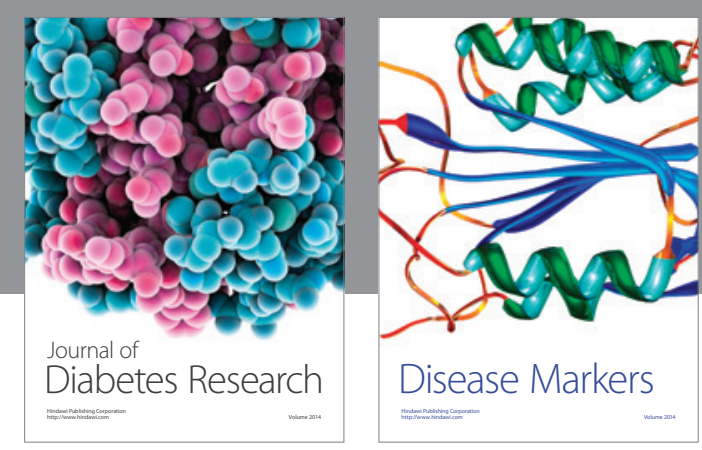

Disease Markers
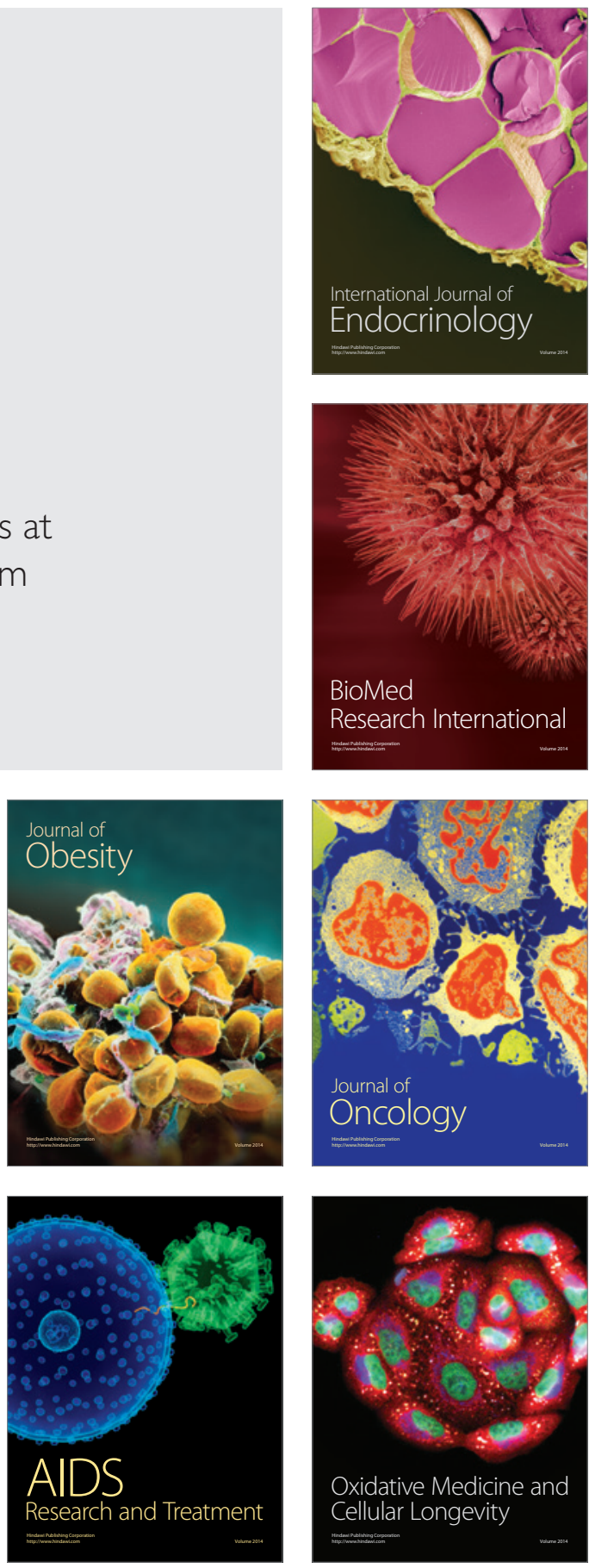